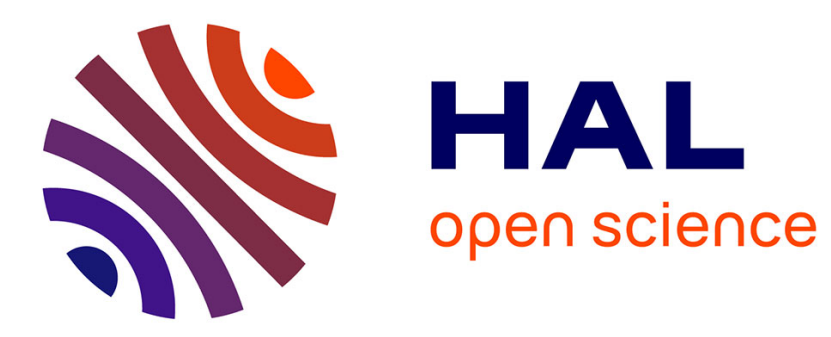

\title{
Defining diagnostic criteria to describe the role of rift inheritance in collisional orogens: the case of the Err-Platta nappes (Switzerland)
}

\author{
Marie-Eva Epin, Gianreto Manatschal, Méderic Amann
}

\section{To cite this version:}

Marie-Eva Epin, Gianreto Manatschal, Méderic Amann. Defining diagnostic criteria to describe the role of rift inheritance in collisional orogens: the case of the Err-Platta nappes (Switzerland). Swiss Journal of Geosciences, 2017, 110 (2), pp.419 - 438. 10.1007/s00015-017-0271-6 . hal-01864629

\author{
HAL Id: hal-01864629 \\ https://hal.science/hal-01864629
}

Submitted on 27 Nov 2021

HAL is a multi-disciplinary open access archive for the deposit and dissemination of scientific research documents, whether they are published or not. The documents may come from teaching and research institutions in France or abroad, or from public or private research centers.
L'archive ouverte pluridisciplinaire HAL, est destinée au dépôt et à la diffusion de documents scientifiques de niveau recherche, publiés ou non, émanant des établissements d'enseignement et de recherche français ou étrangers, des laboratoires publics ou privés. 


\title{
Defining diagnostic criteria to describe the role of rift inheritance in collisional orogens: the case of the Err-Platta nappes (Switzerland)
}

\author{
Marie-Eva Epin ${ }^{1}$ (1) - Gianreto Manatschal ${ }^{1} \cdot$ Méderic Amann $^{1}$
}

Received: 30 July 2016/Accepted: 16 March 2017/Published online: 4 April 2017

(C) Swiss Geological Society 2017

\begin{abstract}
It is commonly accepted that collisional orogens involve the reactivation of former rifted margins. While it remains debated how rift inheritance can be identified and how it controls the architecture of orogens this case study analyses the importance of rift-inheritance during reactivation of a passive margin. The study analyses complex, non-layer cake rift structures within the well-exposed Err and Platta nappes (SE Switzerland), representing the former distal Adriatic margin of the Alpine Tethys. Diagnostic criteria for rift inheritance include: (1) typical fault rocks with a mantle derived fluid signature, and (2) tectonosedimentary breccias made of reworked exhumed basement and grading upwards into late syn- and post-rift sediments. Based on the study of "recognisable" features, a methodology is etablished, which enables to (1) map riftrelated detachment faults and (2) to analyse their role during reactivation and formation of a thrust stack. First, second and third order thrust systems are defined. First order thrust systems juxtapose different rift domains (proximal, necking, and distal). Second order systems are dominantly made up of basement sheets sampling the former footwall of an extensional detachment fault. Third order systems mainly consist of the former hanging wall of an extensional detachment fault. A major result of this study is that thrust faults commonly reactivate former extensional detachment faults, especially in the exhumed mantle domain (Platta nappe), while in the hyperextended
\end{abstract}

Editorial handling: C. Sue and S. Schmid.

Marie-Eva Epin

meepin@unistra.fr

1 IPGS, EOST-CNRS, Université de Strasbourg, 1, Rue Blessig, 67084 Strasbourg, France domain (Err nappe) reactivation of rift-inherited structures is more complex and often incomplete. The results of this study may help to better identify remnants of former distal margins and to define and analyse their complex stacking patterns observed in many internal parts of collisional orogens.

Keywords Reactivation - Rift inheritance - Distal margin · Err-Platta nappes · Grisons · Alps

\section{Introduction}

The Lower Austroalpine Err and Upper Penninic Platta nappes in SE-Switzerland preserve one of the best-documented distal margins including an Ocean-Continent Transition (Dietrich 1970; Trümpy 1975; Froitzheim and Eberli 1990; Manatschal and Nievergelt 1997; Masini et al. 2012). Therefore, the study of these nappes enables to investigate how rift-inherited structures of a former distal rifted margin control the reactivation and formation of a collisional orogen.

The Err-Platta nappe system has been intensely studied for almost a century (Steinmann 1925, 1927; Staub 1946; Trümpy 1975) using stratigraphic (Furrer et al. 1985; Eberli 1988), petrological (Trommsdorff et al. 1993; Desmurs et al. 2002; Müntener et al. 2004) and structural (Dürr 1992; Froitzheim and Manatschal 1996 and references therein) methods highlighting a complex Alpine and preAlpine evolution. In the past, tilted blocks bounded by high-angle normal faults were considered to be the major building blocks inherited from the rifted margin (Montadert et al. 1979; Handy 1996). Recent investigations showed, however, that extensional detachment faults and related extensional allochthons are the dominant structures forming distal parts of magma-poor rifted margins (Boillot 
et al. 1980; Whitmarsh and Wallace 2001; Osmundsen and Ebbing 2008; Reston 2009; Unternehr et al. 2010). The discovery of such structures in the Err and Platta nappes (Froitzheim and Eberli 1990; Manatschal and Nievergelt 1997; Wilson et al. 2001; Masini et al. 2011) went along with the description of similar structures in other locations in the Alps (e.g. Tasna nappe; Florineth and Froitzheim 1994; Manatschal et al. 2006).

At present, the extensional detachment faults found and described in the Alps by Froitzheim and Eberli (1990), Florineth and Froitzheim (1994), Manatschal and Nievergelt (1997) are the best described and exposed examples of these types of structures related to hyperextension and mantle exhumation world-wide. Although most of these structures were partly reactivated during their emplacement in the Alpine orogen, remnants of the extensional detachment system are still locally preserved. This enables to identify diagnostic criteria of these systems, which helps to discriminate between inherited rift structures and compressional structures. Indeed, distinguishing between rift inherited and orogenic structures is a prerequisite to interpret the structural evolution of collisional orogens (Mohn et al. 2011; Beltrando et al. 2014). In most cases the penetrative compressional overprint makes it difficult to recognize the former rift related structures. However, several recent studies described remnants of former distal margins in orogenic belts (e.g. Beltrando et al. 2014) and discussed their importance during reactivation (Butler et al. 2006; Mohn et al. 2014; Tugend et al. 2014). Since in the case of the Err and Platta nappes Alpine overprint is relatively minor, remnants of the former extensional rift system can be confidently identified. In this study we use the ErrPlatta nappe system to: (1) define diagnostic criteria of former distal margins, and, (2) show the control of riftinherited structures during compressional reactivation.

\section{Regional geological setting}

\subsection{Remnants of the distal margin preserved in the Err and Platta nappes}

The study area discussed in this paper is located in SESwitzerland. It comprises the Lower Austroalpine Err and the Upper Penninic Platta nappe system, comprising remnants of the former Jurassic distal Adriatic margin located along the south-eastern Piemonte basin belonging to the Alpine Tethys system. This rift system initiated during Late Triassic-Early Jurassic as a distributed and diffuse rift system before it localized in Late Sinemurian to Pliensbachian time leading to the formation of the future distal margin (Eberli 1988; Froitzheim and Eberli 1990; Mohn et al. 2010). Final rifting related to the exhumation of crustal and mantle rocks and the formation of an embryonic oceanic domain occurred between 180 and 160 Ma (Middle Jurassic), as indicated by the dating of magmatic rocks (Schaltegger et al. 2002) and diagnostic sediments (e.g. Masini et al. 2013 for an overview).

Convergence in the greater Alpine domain started with the closure of the Meliata-Vardar domain during Jurassic time (Ferriere et al. 2016) and migrated into the domain of the Austroalpine nappes discussed in this paper in Cretaceous time (Fig. 1). In the working area the transport direction of the main thrusts was from east/southeast to west/northwest and resulted in the emplacement of a nappe stack that telescoped the former western margin of the northern Adriatic microplate in Late Cretaceous time (for details see chapter below). The external part of this nappe stack includes remnants of the most distal parts of the Adriatic margin, exposed in the Lower Austroalpine and Upper Penninic nappes in the Central and Eastern Alps. During latest Cretaceous to early Cenozoic time, a new subduction zone initiated near the southern margin of the Piemonte basin (Froitzheim et al. 1994; Froitzheim and Manatschal 1996; Froitzheim et al. 2006; Mohn et al. 2012). At this stage, the previously formed, W to NW-vergent nappe stack became the hanging wall of the south-directed subduction that resulted in the closure of the Piemonte basin and eventually the collision of the northern Adriatic microplate with the European plate (Fig. 1). It is important to mention that the Err-Platta nappes were mainly affected, as further discussed below, by the initial and earlier W to $\mathrm{NW}$-vergent stacking resulting in the reactivation and sampling of remnants of the former western Adriatic margin in a fold and thrust belt. Following the work of Froitzheim et al. (1994), this phase will be referred to as the D1 deformation phase. During D1 higher units belonging to the former proximal margin were thrust westward onto the more distal domains of the western Adriatic margin. These Austroalpine and Upper Penninic units remained in the hanging wall of the Alpine subduction and were, as a consequence, relatively little affected by the subsequent latest Cretaceous to Oligocene subduction and collision, which was, in this part of the Alps, N-S directed (Fig. 1). The Err-Platta nappes were located, during this $\mathrm{N}-\mathrm{S}$ shortening, above the singular point of the subduction system, i.e. the point separating retro from pro-thrusting/folding (Beaumont et al. 1996). As a consequence, these units did neither show a strong tectonic nor metamorphic overprint during Cenozoic Alpine convergence. Metamorphism in the study area never exceeded prehnite-pumpellyite facies conditions (Dunoyer de Segonzac and Bernoulli 1976; Ferreiro Mählmann 1994, 1996). This explains the excellent preservation of the rift structures in the northern Err and Platta nappes, which enables to study the early stages of reactivation of the former western Adriatic distal margin. 
(a) 90 Ma: Cenomanian (D1)

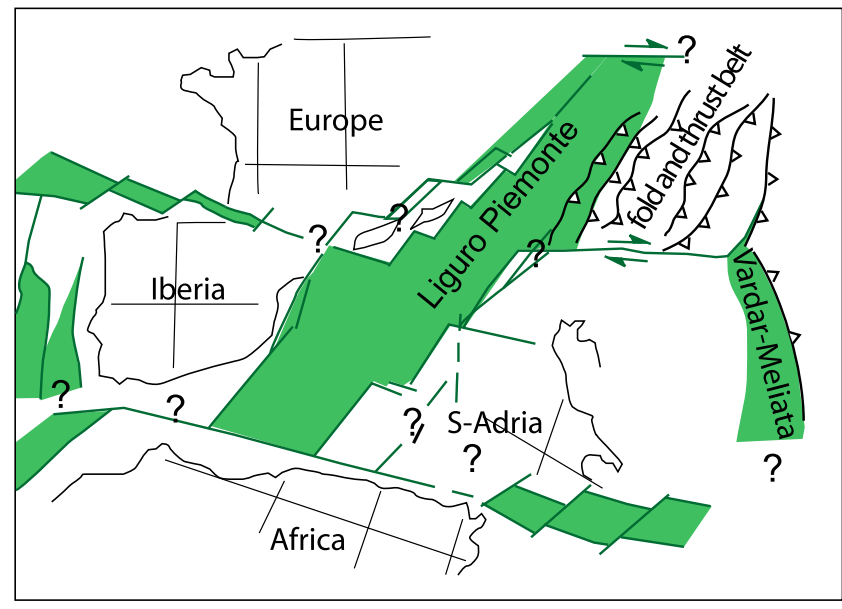

(c) 30 Ma: Oligocene (D3)

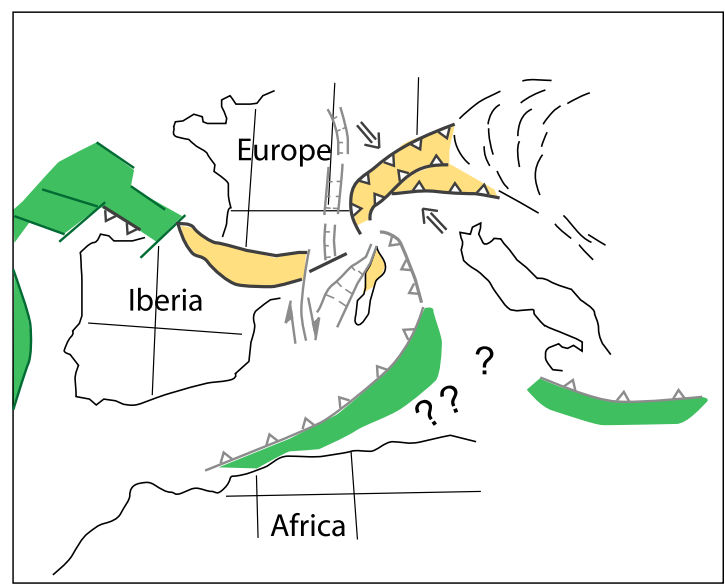

Fig. 1 Paleogeographic maps of the Alpine realm for: a Cenomanian, b Campanian to Maastrichtian, and c Oligocene. d Section shows the Adriatic-European margins during the Late Cretaceous convergence. During this event, the distal part of the Adriatic margin was stacked in

\subsection{Alpine deformation history}

The main Alpine structural evolution leading to the formation of the Late Cretaceous $\mathrm{W}$ to $\mathrm{NW}$-vergent nappe stack and its overprint during the subsequent N-S shortening has been reviewed by Froitzheim et al. (1994) and has classically been subdivided into D1 to D5 phases of deformation (Froitzheim et al. 1994). More detailed structural descriptions of the Err and Platta nappes have been published in Ring et al. (1990), Dürr (1992), Handy et al. (1993) and Manatschal and Nievergelt (1997). The most important structures in the study area are the D1 structures, which are manifested by the emplacement of a top to the west to northwest thrust system (Fig. 1) resulting in the stacking of different rift domains, including the proximal, necking, hyperextended and exhumed mantle (b) 80 Ma: Campanian (D1 + D2)

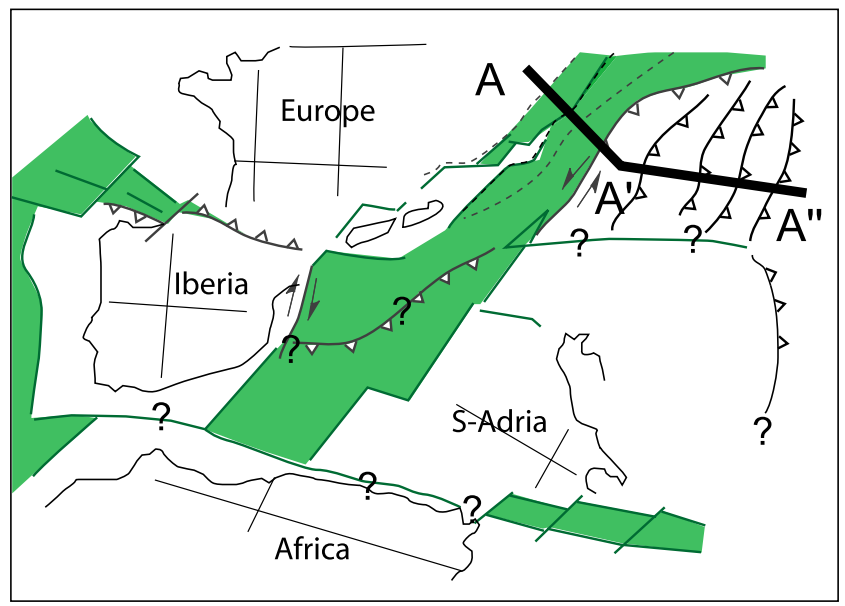

(d) Late Cretaceous

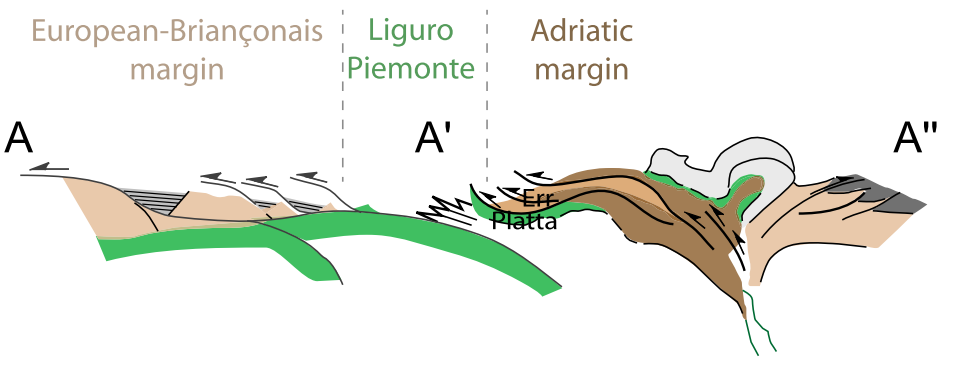

a fold and thrust belt. Note that the western part of the distal northern Adriatic margin was stacked in a fault and thrust belt already before the onset of subduction in the Liguria-Piemonte Ocean. Figure modified after Manatschal and Müntener 2009

domains (Mohn et al. 2011). It appears that the first order D1 structures juxtapose different rift domains. Second and third order D1 thrust structures juxtapose, as discussed later in this study, units derived from the same rift domain. While in the past these D1 structures and their kinematics have been well described, this study will present new observations that enable to describe and discuss the role of inherited rift structures in controlling the formation of D1 structures. The subsequent structures (D2 to D5) are less important in the study area. They include D2 structures that are mainly expressed by top-to-the-SE normal faults that formed during an extensional event predating the onset of $\mathrm{N}-\mathrm{S}$ shortening (D3) related to the subduction of the Piemonte basin (extension less than $3 \mathrm{~km}$; Manatschal and Nievergelt 1997). These structures locally reactivate, but also cut D1 thrusts (Handy et al. 1993; Froitzheim et al. 
1994; Handy et al. 1996; Manatschal and Nievergelt 1997; Masini et al. 2011). The D3 structures correspond to Cenozoic north-south shortening, which is expressed by long wavelength fold structures with E-W trending fold axes and subvertical E-W striking fold axial planes. Locally north- to northwest as well as south-vergent, steeply dipping thrusts with displacements in the order of hundreds of meters can be observed. Younger structures (D4 and D5) are related to late Alpine deformation (e.g. Froitzheim et al. 1994). They consist of high angle normal faults presumably linked to activity along the sinistral Engadine fault, which is a conjugate fault of the Oligocene to Miocene Periadriatic dextral strike-slip system (for further discussion see Trümpy 1977; Schmid and Froitzheim 1993; Handy et al. 1996).

\section{Diagnostic criteria of a distal magma-poor rifted margin}

\subsection{Rift related Jurassic detachment faults}

The Lower Austroalpine Err and Upper Penninic Platta nappes are one of the word's few examples where remnants of a distal margin, including well preserved extensional detachment faults, are beautifully exposed and described. Parts of the Err detachment were first mapped and described by Cornelius (1932) in terms of an Alpine structure. The occurrence of characteristic black indurated fault gouges along this structure (von Rath 1857) and their reworking in Mid-Jurassic sedimentary breccias led Froitzheim and Eberli (1990) to interpret this fault as a Jurassic rift-related detachment fault. This structure preserves primary relationships between crustal and mantle rocks and pre-, syn- and post-rift sediments and magmatic additions. The footwall of the detachment fault system consists either of continental basement, exhumed serpentinised mantle or intrusive magmatic rocks (gabbros). The hanging-wall comprises allochthonous blocks made of continental basement, pre- and syn-rift sediments that are overlain by post-rift sediments or magmatic additions.

\subsection{Fingerprints of fossil extensional detachment faults}

Two major features characterize the paleo-distal margin (Fig. 2): (1) characteristic fault rocks and tectono-sedimentary breccias that are closely linked to the formation of extensional detachment faults, and (2) discontinuous preand syn-tectonic sequences associated with continuous post-rift sequences. Moreover, the juxtaposition of rock types derived from different crustal and mantle levels, sometimes erroneously interpreted as the result of convergence, can also be explained as the result of extreme extension as shown below.

\subsubsection{Characteristic fault rocks and tectono-sedimentary breccias in hyperextended domains}

Remnants of Jurassic extensional detachment faults in the Err and Platta nappes can often be identified thanks to characteristic black and green fault rocks, leucocratic bodies and ophicalcites (Manatschal and Nievergelt 1997, Desmurs et al. 2001). The fault rocks associated with these extensional detachment faults can be distinguished from their Alpine counterparts by the mineralogy, the geochemical signature and their fabrics as well as by the relationship of the fault rocks with the overlying hanging wall, in particular where the faults were exhumed at the seafloor (Manatschal and Bernoulli 1999; Pinto et al. 2015; Incerpi et al. 2017). Indeed, extensional detachment faults can, in contrast to thrust faults, be exhumed at the seafloor and be covered by syn- to post-rift sediments. Due to the fact that they are exhumed, the fault and underlying footwall rocks can also be reworked in the overlying syn-tectonic sedimentary sequence, which is not possible along thrust faults. Therefore, the occurrence of footwall-derived clasts in sedimentary breccias overlying a fault surface is an important criterion to define extensional detachment surfaces.

In the Err nappe, gouges, cataclasites and breccias constitute the principal fingerprints of the Jurassic detachment faults (Fig. 2). They are commonly located at the top of the basement, locally also within the basement (Manatschal and Bernoulli 1999; Manatschal et al. 2000; Pinto et al. 2015). An idealized section across a top-basement detachment fault is represented in Fig. 2c. Such sections start some tens to hundreds of meters below the top of the basement with green, cemented cataclasites (damage zone). The cataclasites have angular clasts of variable size and a fine-grain matrix/cement made of quartz, albite, chlorite and illite. The occurrence of albite, illite and chlorite results from the intense fluid- and reaction-assisted breakdown reactions of feldspars (Manatschal 1999). The main slip surface of the detachment system (core zone) is characterized by indurated black gouges (Froitzheim and Eberli 1990; Manatschal and Bernoulli 1999; Manatschal et al. 2000). They either occur between the hanging wall and the footwall, or, where the basement has been exhumed, at the interface between basement and syn-rift sediments (exhumed detachment surface). In the latter case they are often found reworked within tectono-sedimentary breccias forming the base of the syn-rift sequence overlying exhumed detachment surfaces. These black gouges are centimetre to several metres thick and 


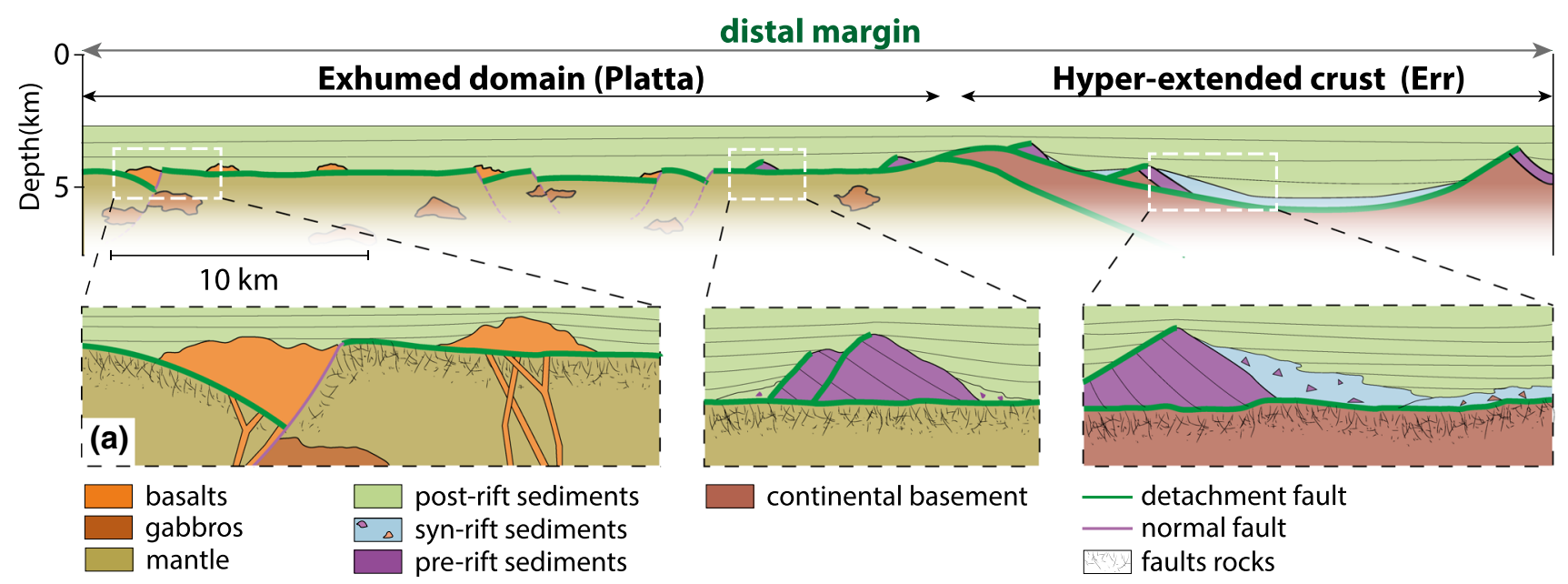

(b) Exhumed domain (Platta)

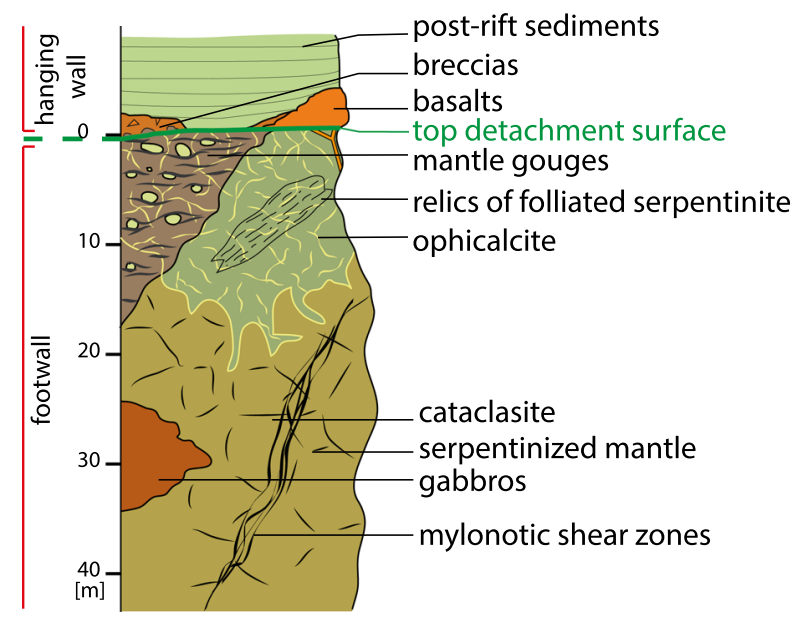

Fig. 2 a Schematic cross-section across the distal Adriatic margin showing the first order architecture of the distal margin before offset of Alpine convergence. Cartoons illustrate the stratigraphic and structural relationships at different locations along the distal margin.

form sharp contacts with the green cataclasites. They show a matrix-supported texture and a scale-independent/fractal fabric. Pinto et al. (2015) showed that in the Err nappe these rocks have a "mantle" chemical signature (enriched in $\mathrm{Cr}, \mathrm{Ni}$, and $\mathrm{V}$ ). The clasts are derived mainly from the footwall and include green cataclasites. Clasts are rounded or elongated and are embedded in a phyllosilicate-rich foliated black matrix. Hanging-wall derived Triassic dolomite clasts are less common but can be observed in the black gouges, clearly showing that these gouges have to be Triassic or younger. Similar fault rocks have also been observed along extensional detachment systems at other hyperextended domains, such as in the Tasna Ocean-Continent-Transition, in the Mauléon basin in the Western Pyrenees or drilled in the present-day Iberia distal rifted margin (Manatschal et al. (c) Hyper-extended crust (Err)

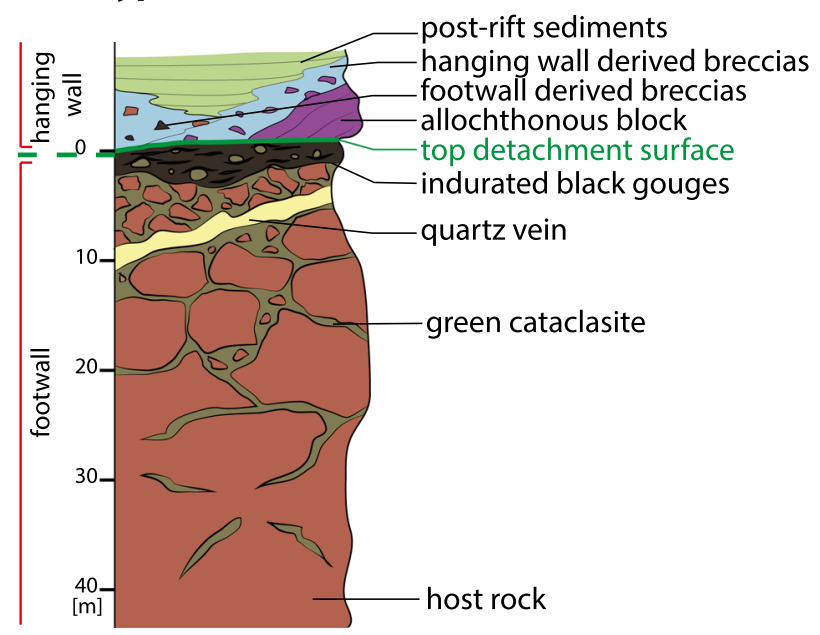

Conceptual sections representing the fingerprints of a detachment system are shown in: b the exhumed mantle domain, and $\mathbf{c}$ the hyperextended domain

2006; Masini et al. 2013). In all these cases they occur along exhumation surfaces showing similar textures, mineralogy and chemical signatures. Another important marker of extensional detachment surfaces is the occurrence of footwall derived breccias (tectono-sedimentary breccias) (Masini et al. 2012). In the Err nappe these breccias correspond to the Saluver A formation (Finger 1978; e.g. basal track of Masini et al. 2012). These breccias are made of polymictic breccias and reddish litho-arenites consisting of the resedimentation of fault rocks and basement rocks derived from the exhumed footwall of the detachment. Similar breccias in an identical position have been drilled along the Iberia margin (ODP Site 1068; Wilson et al. 2001) and are found along all known detachment systems in hyperextended margins (Masini et al. 2011). 


\subsubsection{Characteristic fault rocks and tectono-sedimentary breccias in exhumed mantle domains}

In the Platta nappe, which corresponds to the exhumed mantle domain, serpentinised mantle, serpentinite cataclasites and gouges, ophicalcites and tectono-sedimentary breccias constitute the main fingerprints of Jurassic extensional detachment faults (e.g. Falotta outcrops). These rocks are similar to fault rocks and breccias drilled at several ODP sites along the Iberia-Newfoundland margins (e.g. ODP Sites 1068, 1070, 1277; Manatschal et al. 2001), dredged over slow spreading oceanic ridges or observed in other Alpine type ophiolites (e.g. Manatschal and Müntener 2009; Picazo et al. 2013). An idealized section across a top-basement detachment fault starts some tens to some hundred metres below the top of the basement, with a protolith, often corresponding to a foliated, massive serpentinised peridotite or a gabbro (Fig. 2b). Up-section, fractures and veins filled by syn-kinematic chlorite and serpentine minerals mark the transition into serpentinite or gabbro cataclasites. Bands of localized deformation formed by foliated serpentinite cataclasites occur locally. Mylonitic shear zones are locally observed in mantle rocks and gabbros but they are always overprinted by brittle deformation. The intensity of brittle deformation increases upsection and develops into a core zone, which is formed by serpentinite gouges (for a description see Picazo et al. 2013). Penetrative impregnation and replacement by calcite (Manatschal et al. 2001; Robertson 2007) is observed near the seafloor, which forms characteristic "ophicalcites" (Bernoulli and Weissert 1985; Treves and Harper 1994; Treves et al. 1995). The occurrence of tectono-sedimentary breccias made of reworked exhumed mantle rocks, locally also containing continent-derived clasts, overlies the exhumed subcontinental mantle. The occurrence of ophicalcites resulting from the interaction between serpentinised mantle and seawater, and indicating exhumation of mantle at the seafloor, was firstly interpreted by Decandia and Elter (1972), Bonatti et al. (1974) and Bernoulli and Jenkyns (1974). Today, brittle fault rocks, i.e. cataclasites and gouges associated with ophicalcites and tectono-sedimentary breccias are widely recognized from mid-ocean ridges (e.g. Bonatti et al. 1974; Escartín et al. 2003; Boschi et al. 2006; Lagabrielle and Bodinier 2008) and have been drilled along the Iberia-Newfoundland margins (e.g. ODP Sites 1068, 1070, 1277; Manatschal et al. 2001). Indeed, all drill sites that penetrated basement along the Iberia-Newfoundland margins sampled sedimentary breccias that pass down-hole into tectono-sedimentary breccias that overlie brittle, hydrated fault rocks forming the top of the basement. The detachment surface is sealed by post-rift sediments or by magmatic additions; locally it is overlain by continent derived blocks. This complex, but very characteristic association of rocks, with well-defined textures, chemical signatures and mineralogy as exemplified in the Platta nappe, enables to identify and map remnants of ancient extensional detachment surfaces in the exhumed mantle domain. In this study we use these criteria to map remnants of former detachments faults.

\subsubsection{Discontinuity of pre- and syn-rift sequences and continuity of post-rift sequences}

As shown in Fig. 2a, the rift architecture at distal margins is characterized by non-continuous layers with isolated continent derived blocks and punctual magmatic extrusions constructing over exhumed fault surfaces, altogether sealed by post-rift sediments. The best-documented example is the large allochthonous block drilled at ODP Site 1069 along the Iberia Abyssal Plain (Wilson et al. 2001; Péron-Pinvidic et al. 2007). The occurrence of such extensional allochthons, floored by a continuous, hydrated top basement is probably the principal characteristic of present-day and fossil distal margins.

In the Err and Platta nappes the hanging walls of the Jurassic extensional detachment faults are preserved in the area of Piz Err-Piz Jenatsch in the northern Err nappe (Fig. 3). The allochthonous blocks observed in this area consist of continental basement and pre- and early syn-rift sediments. It is important to note that such pre-rift sequences form isolated allochthonous blocks that are bounded by syn-tectonic sediments and sandwiched between two continues marker horizons, namely the detachment fault surface and the base of the post-rift sequence. In the example of the Err and Platta nappes, the Upper Jurassic Radiolarian Chert Formation is defined as the first post-rift sediment in the sense that they are the first sediments that the cherts overlie embryonic oceanic crust (Mid Ocean Ridge Basalts; MORB) and seal the rift structures in the adjacent continental margin (Trümpy 1975). They are overlain by micritic limestones with intercalations of shales and calcarenites referred to as Aptychus or Calpionella limestone, Upper Jurassic to Lower Cretaceous in age; and the Argille a Palombini Fm., which is considered to be of Lower Cretaceous to Albian age (Weissert and Bernoulli 1985). In the Platta nappe, magmatic additions (MOR-basalts) occur locally over exhumed mantle and are time-equivalent of the early postrift sediments, i.e. the Radiolarian Chert Formation. The magmatic additions consist principally of tholeiitic MORbasalts (Desmurs et al. 2002) that become more voluminous oceanwards and are locally observed to cover exhumed mantle rocks. In most of these examples, the basalts are formed by pillow breccias and hyaloclastites.

Thus, while post-rift sediments were deposited in a subhorizontal position and were passively onlapping on a 

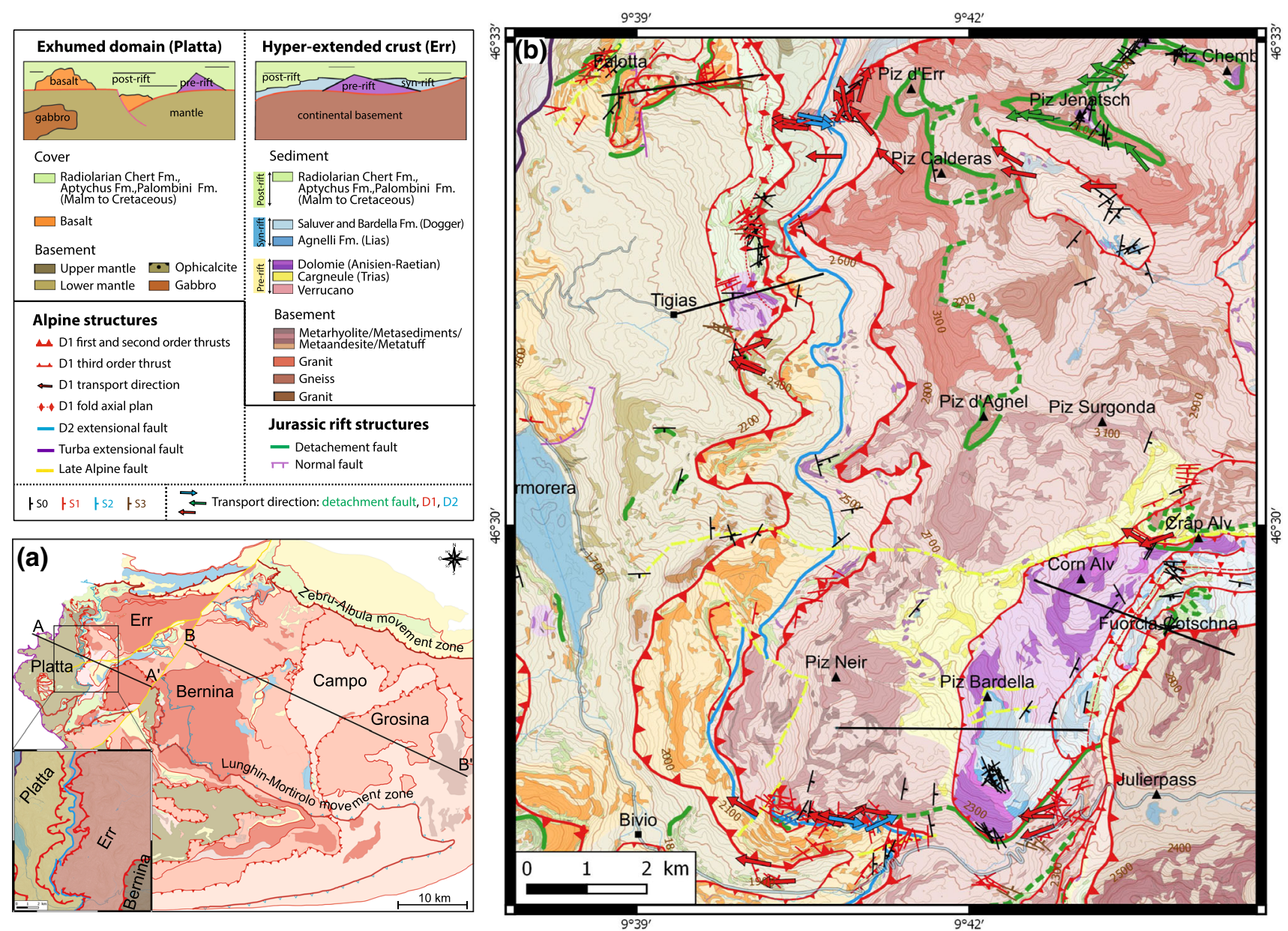

Fig. 3 Tectonic and geological map of the Lower Austroalpine and Upper Penninic Err and Platta nappes in SE-Switzerland. a Geological map of the Austroalpine and Upper Penninic nappes modified after Mohn et al. 2011, sowhing location of the geological map Fig. 3b and section AA'BB' in Fig. 8b. Inset shows simplified tectonic map of the tree major tectonic units (Bernina, Err, and Platta) and major, first

residual topography inherited from the rift stage, the preand syn-rift sequences show more complex and less continuous sequences. They were disrupted already before the onset of convergence and can therefore not be considered as simple "layer-cakes". This is important when studying remnants of former distal margins in orogens, since the lack of continuity is often misinterpreted as the result of poly-phase compressional deformation.

\subsection{Continent derived blocks associated with serpentinised mantle}

The occurrence of blocks of continental origin within sequences made of serpentinites, MOR-basalts and gabbros have often been interpreted as tectonic "mélanges" formed during subduction (Hsü and Briegel 1991). However, similar rock associations have been drilled at present day order D1 structures. b Geological map of the Err and Platta nappes compiled after Cornelius 1932; Cornelius and Clar 1935; Staub 1946; Cornelius 1950; Spillmann and Büchi 1993; Froitzheim et al. 1994; Manatschal 1995; Peters 2005; Trommsdorff et al. 2005; Peters 2007 and own observations

Ocean-Continent-Transitions (see results of ODP drill Sites 1068, 1070, 1277; Manatschal et al. 2001). Yet, tectonic mélanges related to subduction should result in random mixing of basement and sediments and should therefore lack any stratigraphic layering (see Gerya et al. 2002; Beltrando et al. 2010), while associations derived from distal margins show the characteristic fingerprints discussed in the previous sections. Thus, looking for these fingerprints enables to distinguish between the two scenarios i.e. juxtaposition of crustal and mantle rocks in a subduction or collisional setting or during the formation of a distal margin. In the latter case, the juxtaposition typically occurs along brittle extensional faults that are formed by characteristic fault rocks and along which footwall derived rocks are found reworked in tectono-sedimentary breccias overlying an exhumation fault (for details see previous section; Fig. 2). 


\section{Distribution and kinematics of major Jurassic rift-related and Alpine orogenic structures}

In Fig. 3 we present a new geological and structural map using existing and own observations of the area north and west of the Julier valley and confined in the north along a line linking Falotta-Piz Err-Piz Jenatsch. We mapped the distribution of Jurassic detachment faults (green lines in Fig. 3b) using the previously described diagnostic criteria, which enables to define and map the continuity of these structures.

Alpine structures include D1 Alpine thrust faults that are represented in the map in Fig. 3 by thick red lines. D1 structures separate nappes that were stacked in sequence from east to west and include from top to base the Bernina, Err and Platta nappes (Fig. 3a). Second and third order D1 Alpine thrust faults are represented by thinner red lines (Fig. 3b). In this study we will show that most of the third order D1 thrust faults reactivate former Jurassic detachment faults. Alpine D2 structures (blue line in the map Fig. 3) are only locally observed in the study area and do not affect the areas further discussed in this study. Alpine D3 structures are manifested by large scale east and west plunging folds, with subvertical steep east-west striking fold axial planes, and minor south and north vergent thrust faults. Since offsets along these faults never exceed $300 \mathrm{~m}$ and transport direction is always $\mathrm{N}-\mathrm{S}$ directed, we will not include these faults in our E-W oriented restored sections.

In Fig. $3 b$ we compiled existing and new kinematic and structural data for both the Jurassic and Alpine structures. Our data show, in line with previous studies (Froitzheim et al. 1994; Manatschal and Nievergelt 1997; Masini et al. 2011) that the kinematics of the two major fault systems, the Jurassic and Alpine D1 faults, are approximately colinear both associated with E-W to SE-NW trending transport directions.

\section{Reactivation of rift-inherited structures}

In this chapter we focus on two examples where the interplay between rift-inherited structures and Alpine D1 structures is well exposed and not heavily overprinted by later Alpine events. The aim is to describe the interplay between rift-structures and Alpine D1 structures during reactivation. Based on the observation that the two phases are co-linear and show the same E-W to SE-NW directed kinematic transport direction we will construct and cinematically restore $\mathrm{E}-\mathrm{W}$ directed sections that correspond to the former dip sections across the distal margin.

\subsection{Bardella-Fuorcla Cotschna area (hyperextended domain)}

\subsubsection{Geological overview}

The Piz Bardella-Fuorcla Cotschna area is well-exposed over $50 \mathrm{~km}^{2}$ in the area north of the Julier Pass (Fig. 4). Maps and detailed structural analysis have previously been presented in Handy et al. (1993), Froitzheim et al. (1994), Manatschal and Nievergelt (1997). In this study we define 5 subunits, all separated by third order Alpine D1 thrusts, and sandwiched between the Bernina and the Platta nappes along major D1 structures (Fig. 3). This top to the west nappe stack has been overprinted by minor south and north vergent D3 thrusts that will not be further discussed.

As shown in Fig. 4c, subunit 1 is limited at its top by the Bernina thrust and at the base by a minor thrust that juxtaposes a granitic basement over syn-rift sediments. Subunit 2 is delimited at its base by a thrust that juxtaposes little deformed syn-rift sediments against post-rift sediments. Subunit 3 consists of a kilometre scale D1 fold that is delimited at its base along a thrust by pre- and syn-rift sediments. The fold axial plane of this north to northwest vergent synclinal fold dips with $30^{\circ}$ to the south. It includes a complete section of pre- to syn-rift sediments (Bardella and Saluver Fms.) and post-rift sediments (Upper Jurassic Radiolarian Chert Formation and Upper Jurassic to Lower Cretaceous limestones). Subunit 4 is confined at its base by a thrust that juxtaposes Verrucano and meta-rhyolites onto cargneules and dolomites belonging to the pre-rift sequence. The evaporitic pre-rift sequence occurs only locally along the contact and is substituted by cargneules, leaving only relics of gypsum in cargneules to the south of the Corn Margun area (Naef 1987; Peters 2007). Further west subunit 5 contains thick meta-rhyolite, Verrucano sandstones, cargneules and relics of pre-rift dolomite. This unit overlies, along a D1 thrust contract, basalts and serpentinites belonging to the Platta nappe. All thrust contacts show old over young and a consistent top-to-the west sense of shear.

\subsubsection{Composition of the subunits}

Remnants of basement and pre-rift sediments occur in subunits 1, 3, 4 and 5 (Fig. 4c). Subunits 1 and 4 contain cataclasites and black gouges that are fingerprints of former Jurassic detachment faults (see previous section and Fig. 2). In subunit 1 a pre-Alpine rift related detachment structure is well preserved. This structure, previously described by Handy et al. (1993), Manatschal and Nievergelt (1997) and Masini et al. (2011), shows a granitic basement dominated by a strong cataclastic overprint and the occurrence of characteristic black gouges, overlain by 

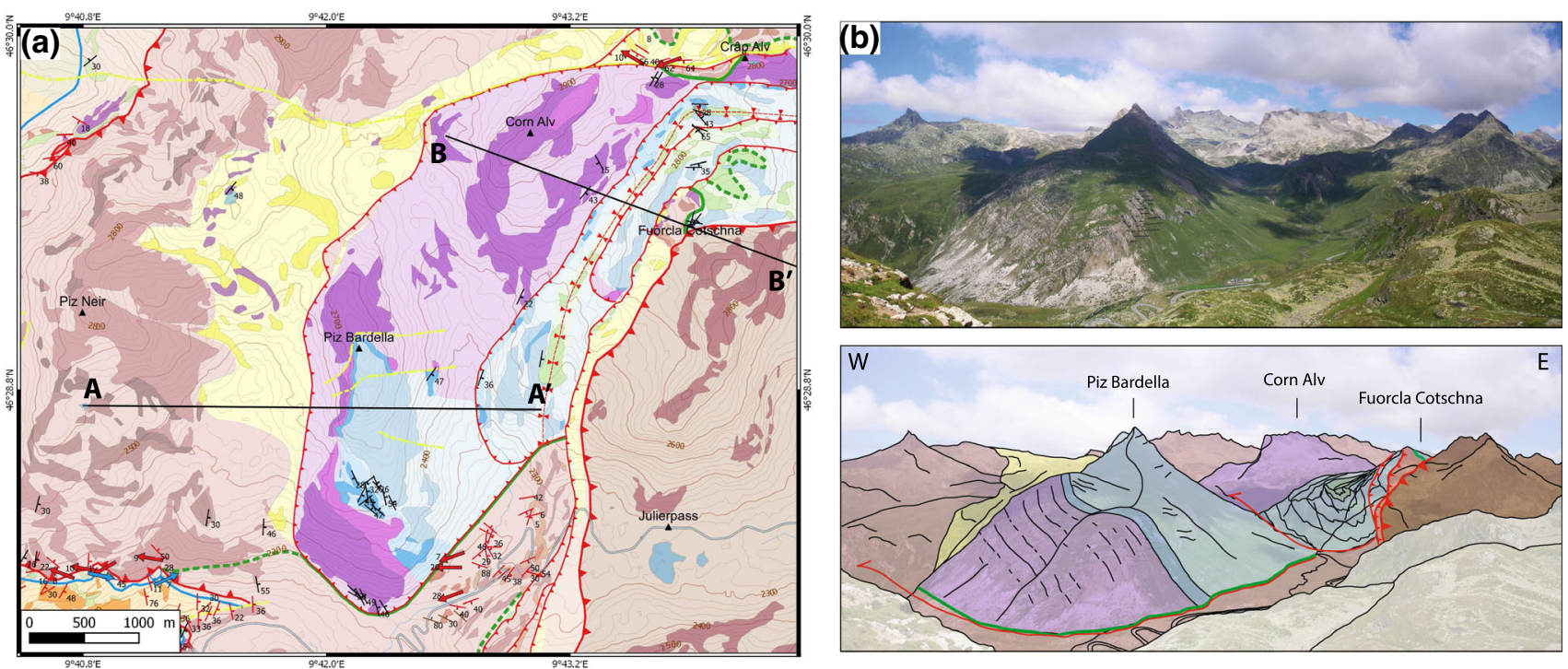

(c)

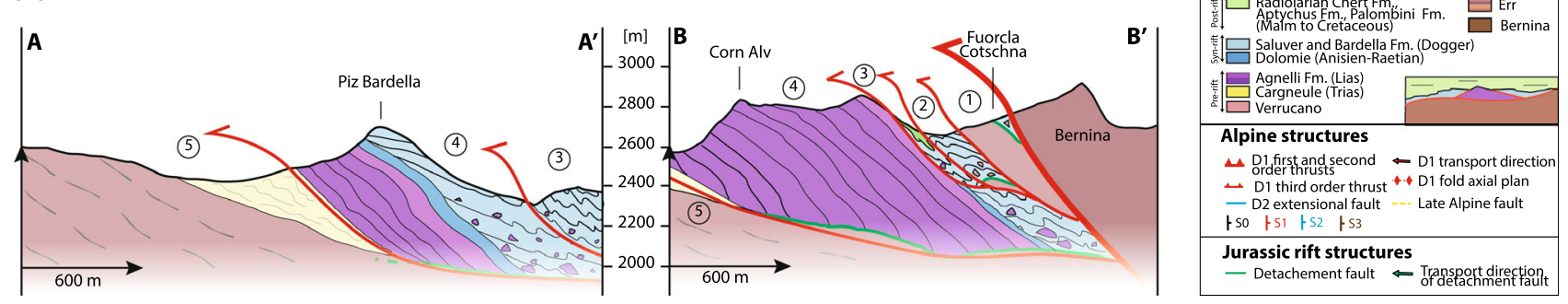

Fig. 4 a Geological map of the Bardella-Fuorcla Cotschna area. b Photograph and line drawing of the panoramic view of the Piz Bardella-Fuorcla-Cotschna area (view from the south). c Geological

syn-tectonic sediments. A key observation is that the overlying sediments are only little deformed and the contact to the strongly deformed basement is depositional. This is further supported by the fact that the black fault gouges are reworked within the overlying sediments. This observation shows that this structure had to be pre-Alpine and that the detachment had to be exposed at the seafloor in Jurassic time. The shallow angle between the sediments deposited over the exhumed basement and the exposed top basement shows that the footwall had to be shallow dipping to sub-horizontal when exposed at the seafloor.

In subunit 4 (Fig. 4c) another remnant of the detachment system is preserved as indicated by the occurrence of back gouges and green cemented cataclasites. These rocks occur along the contact between crystalline basement, metarhyolite and red immature sandstones (Verrucano) in the footwall and pre-rift Triassic dolomites dipping with $46^{\circ}$ towards the east in the hanging wall. Panoramic view and map (Fig. 4a, b) show that these pre-rift dolomites wedge out south-eastwards. The top of the pre-rift sediments corresponds to an angular unconformity between early synrift (Agnelli Fm.) and late syn-rift sediments (Bardella and Saluver Fm.; Masini et al. 2011). section $\mathrm{AA}^{\prime}$ and $\mathrm{BB}^{\prime}$ located on the geological map shown in (Fig. 4a). Subdivision in subunits (1-5) defined on the basis of Alpine D1 thrusts

Except for subunit 5 (Fig. 4c), syn-rift sedimentary breccias can be found in all other subunits. It is important to note that their composition changes from pre-rift derived carbonate dominated breccias (Bardella Fm.) in subunit 4 to predominantly basement derived syn-rift breccias and sandstones (Saluver Fm.) in subunit 1. The increase of basement derived clasts going from subunit 3 to 2 and 1 (Fig. 4c) reflects the disappearance of the Triassic dolomites as a local source and the appearance of basement as a new source. This observation is compatible with the disappearance of the pre-rift Triassic dolomites in subunits 3 to 1 (Fig. 4c) and deposition of syn-rift sediments directly over exhumed basement. These observations show that the pre-rift Triassic dolomite had to be discontinues and floored by a Jurassic extensional detachment fault.

The change in composition of the breccias from hanging wall- to footwall-derived has been explained by Masini et al. (2011) to reflect the progressive extension along detachment faults. Thus, despite of the changes in composition in the syn-tectonic sedimentary sequence within the different subunits, the sediments have been interpreted to derive from one and the same depositional environment (e.g. Masini et al. 2011). This is supported by the 
observation that the post-rift sediments are the same in all subunits.

\subsubsection{Links between rift inheritance and reactivation}

In the Bardella-Fuorcla Cotschna area characteristic fault rocks (cataclasites, black gouges, and basement derived breccias) can be found together with isolated blocks of pre-rift units, interleaved by syn-tectonic sequences and continuous post-rift sediments stacked within top-to-the west thrust sheets. Detailed mapping shows that the thrust sheets form complex Alpine subunits containing remnants of a Jurassic extensional detachment system. The field observations also indicate that the thrust partly reactivated the inherited Jurassic detachment that was used as a decollement level during reactivation (Fig. 5). Since the kinematics of the Jurassic and Alpine fault systems were approximately co-linear, both trending E-W to SE-NW, a simple qualitative restoration of the Piz Bardella-Fuorcla Cotschna area can be proposed in a section parallel to the transport direction (Fig. 5). The restoration of the 5 subunits, which are at present stacked one on top of each other, puts them back to their pre-Alpine position. Along with the restoration of the thrust sheets, also the major fold observed in subunit 3 has been restored back to the paleo-architecture of the Bardella-Fuorcla Cotschna area prior to Alpine convergence. Based on the observations reported above, the pre-Alpine configuration was not a simple layer cake, but consisted of discontinuous pre-rift blocks (extensional allochthons) floored by a detachment system and sealed by syn- to post-rift sediments. It is important to note that in our restoration we do not restore the pre-rift units back to continuous layers, as often done in restorations, but we align remnants of the detachment system and the post-rift sequence. Thus, the observed juxtaposition of different lithologies (basement, pre- and syn-rift sediments) is not the result of a complex Alpine deformation, but rather the result of in-sequence thrusting during D1 shortening (Fig. 5) that reactivated a complex rift architecture.

\subsection{Falotta-Tigias area (exhumed mantle domain)}

\subsubsection{Geological overview}

The Falotta-Tigias area (Fig. 6) belongs to the Lower Platta unit, which is confined at its top by a major D1 thrust along which the Upper Platta unit was thrust westwards over the Lower Platta unit (Desmurs et al. 2001). At its base the Lower Platta unit is floored by the Turba fault, a midEocene to Early Oligocene normal fault (Nievergelt et al. 1996; Desmurs et al. 2001). The geology of the area is complex due to thrust slices, lateral thickness variations of the basalts and the occurrence of continent derived blocks interleaved between serpentinites, basalts and post-rift sediments.

Mapping of the Tigias-Falotta area enables a subdivion into 7 subunits (Fig. 6). Subunit 1 (Fig. 6c) is constituted of serpentinised mantle that is capped by serpentinite gouges and ophicalcites. This unit can be mapped throughout the Platta nappe and forms the backbone of the Lower Platta unit. In the Falotta area further north, subunit 1 can be subdivided into $1 \mathrm{a}$ and $1 \mathrm{~b}$ (Fig. 6c) subdivided by a high-angle normal fault shown in the map in Fig. 6a with magenta colour. This contact is truncated by a D1 thrust fault and has therefore to be older. Subunit 1 is overlain by subunits $2-7$ that represent thin slices typically floored by ophicalcites and serpentinites and overlain either directly by post-rift sediments (subunit 6), or by basalt and post-rift sediments (subunits 2, 4, 5, 7), or by remnants of crustal basement and a larger piece of a pre-rift Triassic dolomite that is overlain by isoclinally folded Jurassic to Lower Cretaceous post-rift sediments (subunit 3). The overall geometry of the thrust stack is defined by thin duplexes that are separated by top-to-the-west to northwest vergent thrust faults (subunits 2-7) sandwiched between two continuous mantle bodies, corresponding to the upper and lower mantle serpentinite units, the latter corresponding to subunit 1 (Desmurs et al. 2001). Thrust faults limiting the duplexes are typically decoupled along the top of subunit 1 within ophicalcites or along exhumation related serpentinised fault zones. The thrust faults ramp westwards across the cover (basalts and/or post-rift sediments) leading to local repetitions and tectonic thickening of the cover sequence.

\subsubsection{Composition of the subunits}

The occurrence of cataclasites and gouges, ophicalcites and tectono-sedimentary breccias observed at the top of subunit 1 (Fig. 6c) is reminiscent of an extensional detachment fault capping exhumed mantle. Indeed, these rocks are very similar to those drilled during ODP Legs 103, 149, 173 and 210 at the top of exhumed mantle along the Iberia and Newfoundland margin (Picazo et al. 2013).

Another potential pre-Alpine structure is the steep normal fault separating subunits $1 \mathrm{a}$ and $1 \mathrm{~b}$ (Fig. 6c). This structure coincides with thickness variations of basalts and the occurrence of hydrothermal systems and ore deposits (magnetite, chrome, Geiger 1948; Peters 2007). It is important to note that these ore deposits are aligned along this steep, N-S striking structure separating subunits $1 \mathrm{a}$ and 1b. Since this steep normal fault is truncated by a D1 Alpine thrust we interpret it as an oceanic normal fault that offset a previously exhumed mantle surface. 

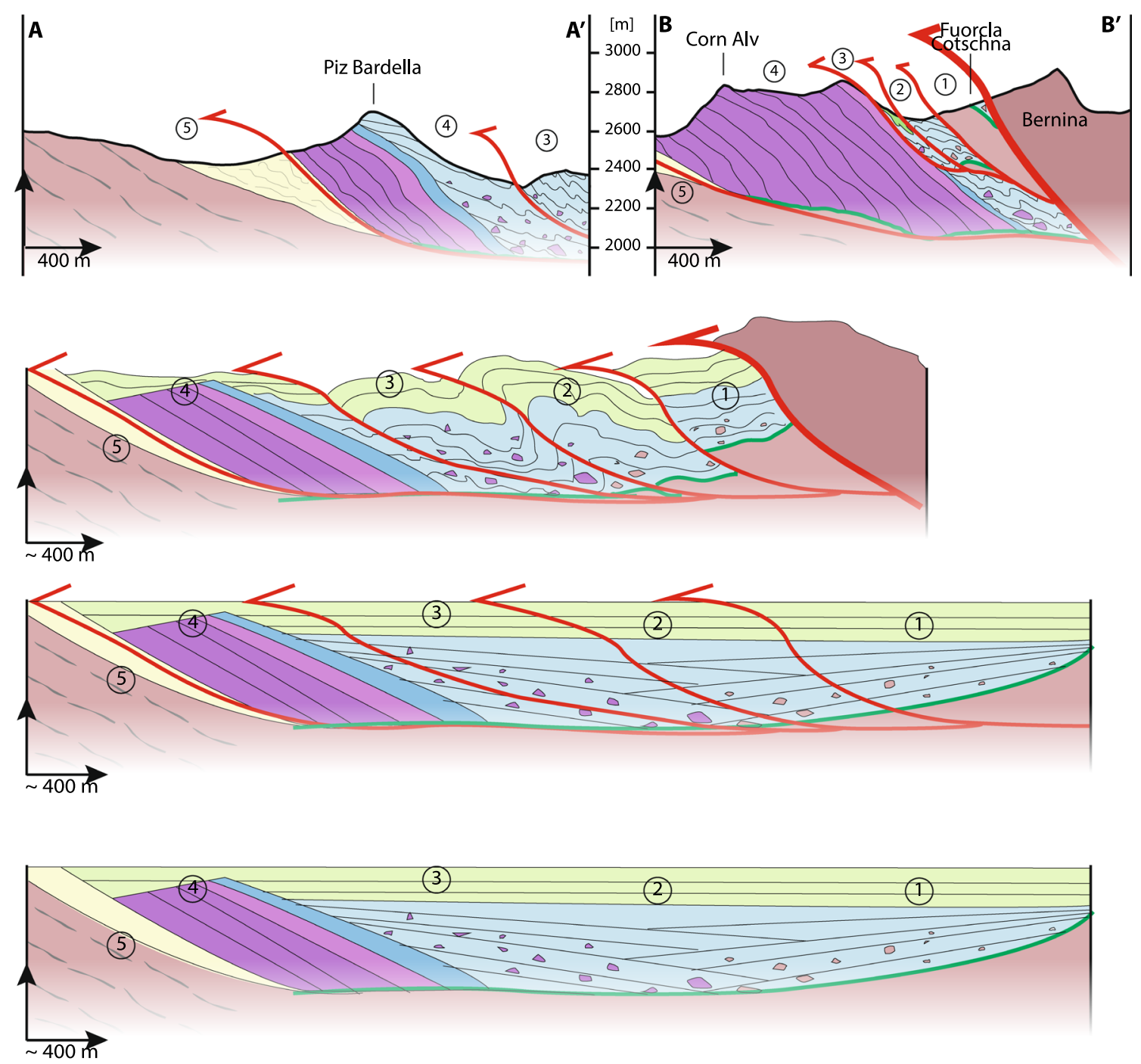

\begin{tabular}{|c|c|c|}
\hline \multicolumn{3}{|c|}{ Hyper-extended crust (Err) } \\
\hline Sediment & Basement & Alpine structures \\
\hline $\begin{array}{l}\text { Radiolarian Chert Fm., Aptychus Fm. } \\
\text { Palombini Fm. (Malm to Cretaceouss) } \\
\text { ât }\end{array}$ & $E$ Err & $\angle$ D1 first and second \\
\hline Saluver and Bardella Fm. (Dogger) & Bernına & $\angle \mathrm{D} 1$ third order thrust \\
\hline $\begin{array}{l}\text { Dolomite (Anisien-Raetian) } \\
\text { Cargneule (Trias) }\end{array}$ & 7 prentit Syn-itit & $\begin{array}{l}\text { Jurassic rift structures } \\
\text { - Detachement fault }\end{array}$ \\
\hline
\end{tabular}

Fig. 5 Restoration of the present-day geological section $\mathrm{AA}^{\prime}$ and $\mathrm{BB}^{\prime}$ back to the end of rifting in late Middle Jurassic time (for location of the present section see Fig. 4a). Note interference between D1 thrust structures and inherited Jurassic rift structures (for further explanations see text)

The continent derived block in subunit 3 (Fig. 6c) is overlain by the Radiolarian Chert Formation containing detritic layers with clasts of gneiss, pillow basalts and grains of spinel (Manatschal and Nievergelt 1997). The mixed detritus shows the proximity of continental and proto-oceanic units during Jurassic time. Thus, the remnants of continental basement and pre-rift dolomites in subunit 3 are best interpreted as representing an allochthonous block overlaying mantle and sealed by post-rift sediments.

\subsubsection{Links between rift inheritance and reactivation}

Since the kinematics of the Jurassic and Alpine fault systems were approximately co-linear, both trending E-W to SE-NW, subunits 1-7 mapped in the Falotta-Tigias area (Fig. 6) can be restored in an E-W section (Fig. 7). The occurrence of serpentinite gouges and ophicalcites at the top of subunit 1 as well as at the base of most of the other subunits show that the major decoupling surface was the top basement. Thus, the exhumation surface corresponding 

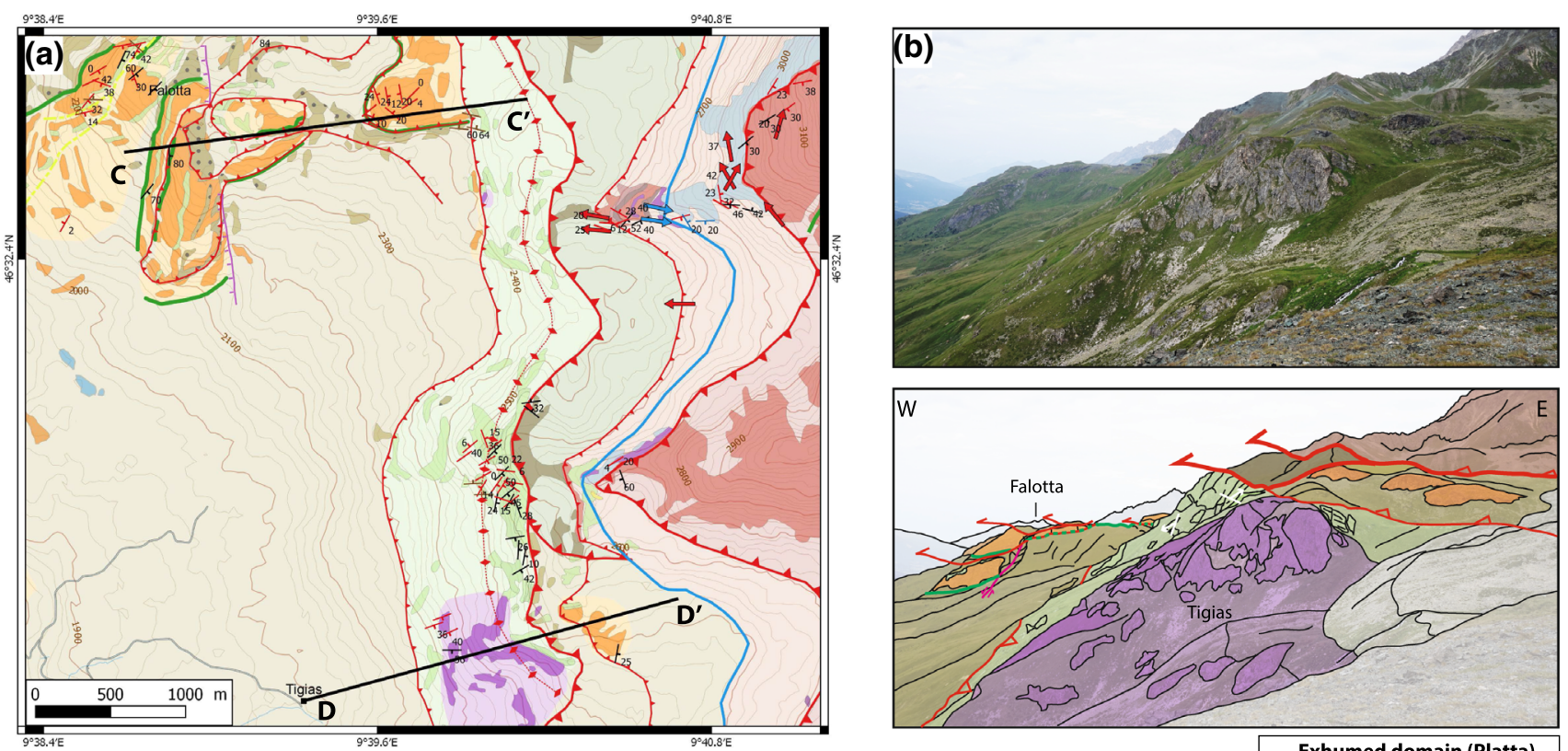

(c)
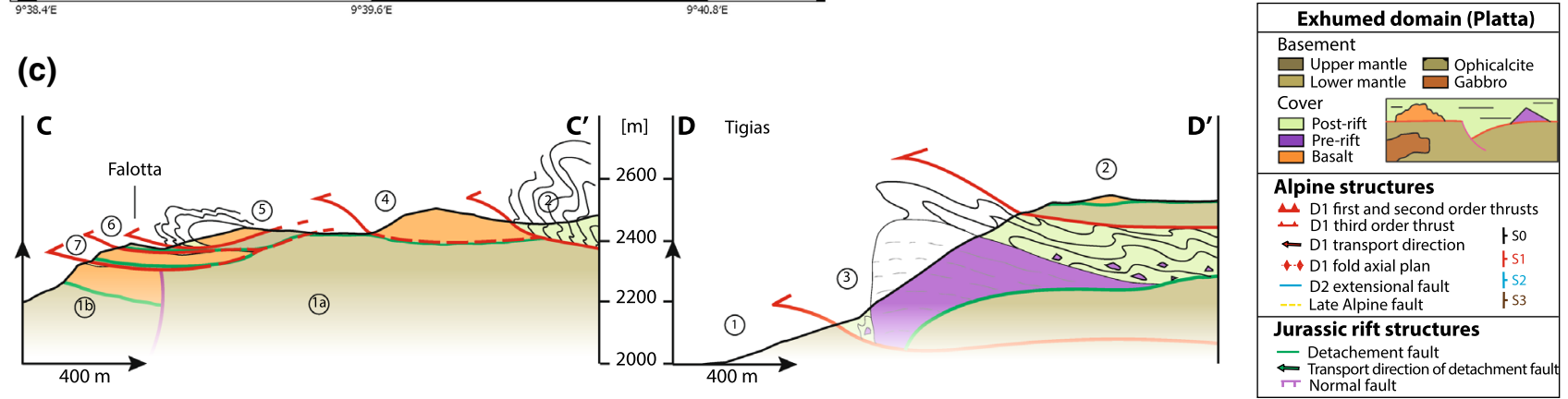

Fig. 6 a Geological map of the Falotta-Tigias area. b Photograph and line drawing of the panoramic view of the Tigias-Falotta area (view from the south). c Constructed sections $\mathrm{CC}^{\prime}$ and $\mathrm{DD}^{\prime}$ cross the

to a Jurassic detachment fault played a key role during reactivation of the margin. The thick slices corresponding to subunits 2-7 sampled the former hanging wall of the exhumed mantle made of volcanic edifices, continent derived blocks and sealed by post-rift sediments. More complex structures such as the stacking of subunits 5-7 may coincide with the occurrence of an oceanic normal fault. Across this fault thickness variations of the basalts can be observed. The occurrence of small continent derived allochthonous blocks or volcanic edifices, laterally confined by post-rift sequences, may have played an additional control on the formation of small duplexes and folds in the post-rift sequence.

\section{Discussion}

Magma-poor distal rifted margins consist of a complex arrangement of hyperextended continental crust and exhumed mantle. Key structures that can be identified in
Falotta-Tigias area (for location of the sections see geological map shown in Fig. 6a. Subdivision in subunits (1-7) defined by Alpine D1 thrust faults

these settings are extensional detachment faults overlain by allochthonous blocks that are interleaved with syn-rift sediments and sealed by post-rift sediments. Oceanwards magmatic additions, often associated with syn-magmatic faults, occur and overprint older exhumation faults. Due to the complex, non-layer cake nature of these domains, their identification in collisional orogens is difficult, and as a matter of fact, very controversial. Therefore we focus here on the Err and Platta nappes, where an extensional detachment system has been described in detail (e.g. Masini et al. 2012 and references inhere). The results of this previous work, together with the weak Alpine tectonic and metamorphic overprint, enable the identification of diagnostic fingerprints of former distal margins and to map their structures and investigate their role during Alpine reactivation. Therefore, the following discussion focusses on three main questions: (1) what criteria can we use to identify remnants of a fossil distal margin in an orogenic setting, (2) how does rift inheritance control reactivation, and (3) how can small scale outcrop observations be up- 

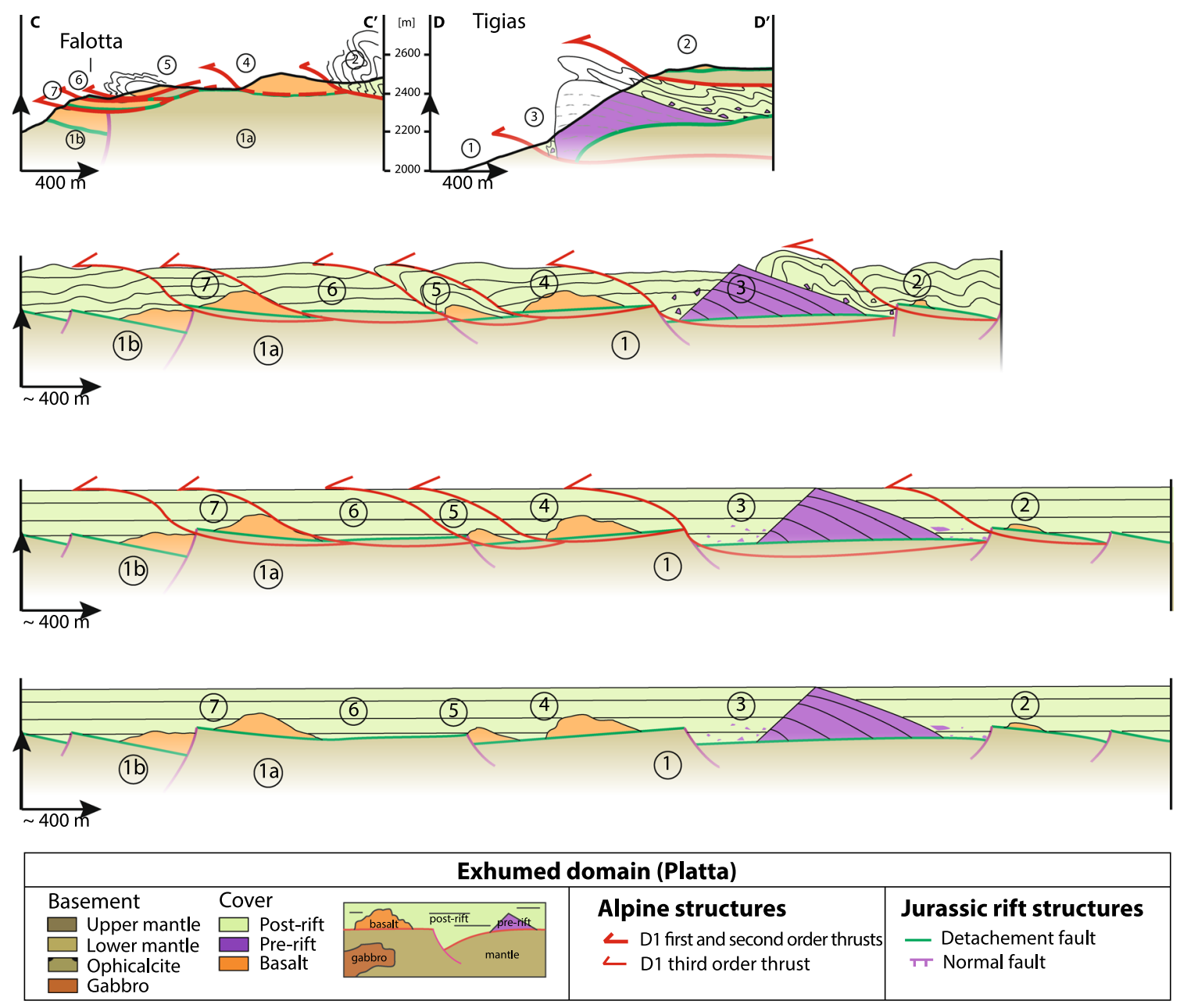

Fig. 7 Restoration of the present-day geological sections $\mathrm{CC}^{\prime}$ and $\mathrm{DD}^{\prime}$ back to the late Middle Jurassic situation (for location of the sections see Fig. 6a). Note interference between D1 thrust structures and inherited Jurassic rift structures (for further explanations see text)

scaled and thrust structures be hierarchized and linked to inheritance. The discussion is based on the observations and maps realised in the Err and Platta nappes presented in this work.

\subsection{Using diagnostic criteria to identify remnants of distal margins in orogenic domains: a methodological approach}

The pioneering studies of Steinmann (1925), Cornelius (1932), Dietrich (1970) and Stöcklin (1974) suggested, based on field observations, a very similar tectonostratigraphic evolution of the Err and Platta nappes. These observations were refuted after the advent of the plate tectonic theory. The major argument was that the juxtaposition of rocks of crustal and mantle origin could not be reconciled with plate tectonic models. As a consequence, all structural complexities became imperatively interpreted as being related to complex collisional processes. In the case of the Platta nappe, the occurrence of continental and mantle derived material was interpreted by some workers as the result of "tectonic mélanges" (Hsü 1995; Dürr 1992). However, drilling and seismic imaging of the most distal parts of the Western Iberia rifted margin and its comparison with outcrops in the Err and Platta nappes showed that the observed "complexity" is not the result of Alpine deformation only, but is also partly inherited from the former rifted margin (Manatschal and Bernoulli 1999; Wilson et al. 2001). The studies of Froitzheim and Eberli (1990), Desmurs et al. (2001), Manatschal (2004) and Masini et al. (2012) provided a description of the structures related to hyperextension and exhumation during Jurassic rifting. Based on these studies and their comparison with present-day rifted margins, it became possible to define diagnostic criteria that enable to 
identify remnants of former distal margins in collisional orogens. However, at present there are only few systematic studies in which these diagnostic criteria have been defined and used to map and describe the role of these structures for the subsequent reactivation. The Err and Platta nappes represent, due to the weak tectonic and metamorphic overprint, one of best places to develop and test a methodological approach to identify and study the role of rift inheritance during reactivation of a distal margin. The approach used in this study includes four major steps, which are:

(1) identification of the major and minor Alpine deformation phases responsible of the stacking of so called "coherent thrust sheets" corresponding to internally coherent remnants preserving structures inherited from the former margin;

(2) mapping of these coherent units and identification of the kinematics of their emplacement;

(3) search for diagnostic criteria to identify the occurrence of inherited rift structures in these coherent thrust sheets;

(4) kinematic and palinspastic restoration of the thrust sheets.

A major difference to classical restorations is the analysis carried out during step 3. Classical restorations tend to overemphasise the importance of tilted blocks and to restore pre-rift sedimentary units back to continuous sub-horizontal layers (e.g. "layer cake concept"). However, observations at modern, seismically imaged and drilled distal magma-poor rifted margins (e.g. Peron-Pinvidic et al. 2013) show that these domains are characterized by: (1) discontinuous pre- and early syn-rift sequences and continuous post-rift sediments, and (2) juxtaposition of crustal and mantle rocks along brittle extensional detachment systems. Although in detail the mapped units (e.g. coherent thrust sheets, here called subunits) consist of complex associations of rocks, the occurrence of characteristic rocks-types enables to identify and map remnants of former extensional detachment faults and to reconstruct them by the kinematic inversion of the Alpine deformation. Characteristic rocks of distal margins are ophicalcites, silicified cataclasites and gouges with characteristic geochemical fingerprints assocaited with tectono-sedimentary breccias reworking exhumed basement rocks. This paper is the first which uses this approach in a rigorous way to map the inherited structures and to investigate their control on the reactivation of a former distal margin. Ignoring "rift" inheritance in orogenic settings, in particular in internal parts of orogens, may significantly change the structural interpretations of collisional belts as shown in the example of the Err and Platta nappes.

\subsection{Role of rift inheritance in reactivation of distal margins}

\subsubsection{Reactivation of a hyperextended domain}

In the Piz Bardella-Fuorcla Cotschna area (Fig. 4) folds and thrusts overprint inherited rift- structures. The most prominent inherited structure is an extensional detachment fault, which can be identified in subunits 1 and 4 (Fig. 4 and 5). While in the case of Fuorcla Cotschna in subunit 1 (Fig. 6c) the detachment is not reactivated and its contact with syn-rift sediments is preserved (Fig. 7), the former detachment has been reactivated in subunits 3 and 4 . Thus, only some of the pre-existing detachment surfaces are reactivated. Potential factors that may have controlled the reactivation are the original orientation and the morphology of the fault plane. In the cases of complex fault morphologies (lateral ramps, domes or discontinuities due to offsets along later faults), thrust faults cannot copy and reactivate the complete inherited fault surface. In this case the thrust fault can either incise into the footwall or excise into the hanging wall of the inherited detachment system. This can explain the local preservation of primary contacts between extensional detachment faults and the sediments (e.g. Fuorcla Cotschna, Fig. 5), but also their absence (e.g. subunits 2 and 3, Fig. 5). In the example of subunit 4, the extensional detachment fault was partly overlain by Triassic evaporates. The occurrence of these evaporates may have facilitated the reactivation of this surface.

A second observation made in the Piz Bardella-Fuorcla Cotschna area is the occurrence of kilometre scale folds within syn- and post-rift sediments in subunits 2 and 3 (Fig. 5). These large-scale folds are not observed in subunit 4 that is made of a massive block of Triassic pre-rift sediments. This block is interpreted as a kilometre scale, NESW trending extensional allochthon, floored by an extensional detachment fault and defining the north-western termination of a massive syn- to post rift sequence found in subunits $1-3$. We therefore propose that the allochthonous block may have acted as a local buttress for the syn- and post-rift sediments controlling the formation of large-scale folds observed in subunits 2 and 3. This interpretation is compatible with the observation that the strike of this block is parallel to the fold axes of the kilometre scale fold (Figs. 4 and 5).

\subsubsection{Reactivation of an exhumed mantle domain}

In the Falotta-Tigias area (Fig. 6) D1 thrust faults are predominantly located at the top of subunit 1 , i.e. at the top of the massive mantle serpentinite. The overlying duplexes (subunits 2-7) are made up either of basaltic bodies (subunits $2,4,5,6,7$ ) or of continent derived blocks (subunit 
3). All subunits (Fig. 6c) include the same post-rift sequence, some also serpentinites and/or ophicalcites. These observations suggest that top-basement topography played a major control during reactivation (Fig. 7). Volcanoes and extensional allochthons, which likely can be attributed to positive topography, occur in duplexes. This suggests that the occurrence of "ramps" was controlled by the existence of inherited topography, while the "flats" correspond to the reactivation of the former detachment fault localized at the top of the exhumed mantle.

An inherited syn-magmatic oceanic normal fault truncating and offsetting the top of the mantle is observed at Falotta. This fault dips to the west i.e. it was not preferentially oriented for a reactivation by a top-to-the-west thrust system. This may explain the preservation of this structure; however, its presence may also explain the local complexity and stacking of three subunits (5, 6, and 7). In contrast, faults with paleo-dips to the east were probably completely reactivated.

Prominent large-scale isoclinal D1 folds occur in the sediments associated with the major block of pre-rift sediments observed in subunit 3 . These folds may be explained, like in the example of the Bardella-Fuorcla Cotschna area, by local top basement topography acting as local buttresses during convergence (Fig. 7). Other examples may be normal faults offsetting top basement or volcanoes.

\subsubsection{Reactivation of distal margins: hyperextended crust vs. exhumed mantle domains}

The study of the Bardella-Fuorcla Cotschna and the Falotta-Tigias areas enables to investigate and compare the reactivation of two domains that underwent a similar reactivation history but are floored by different types of basement rocks. In both examples reactivation resulted in thin duplexes that sampled supra-detachment material. In both cases decoupling levels are very shallow. It appears, however, that in the hyperextended domain detachment surfaces are more difficult to reactivate, while in the exhumed mantle domain detachment surfaces are commonly reactivated. Extensional detachment systems in the continent may have a more complex geometry due to inherited heterogeneities in the crust. Our observations suggest that they are preferentially reactivated where they are juxtaposed against evaporate and/or clay-rich levels. In the exhumed mantle domain the major decoupling levels are essentially serpentine-rich fault gouges and/or ophicalcites forming the top of the exhumed mantle.

Another factor that appears to be important in controlling reactivation is top-basement topography that is either related to late normal faults, magmatic additions, or extensional allochthons. It appears that in both examples fold amplifications in syn- and post-rift sequences are directly linked to the occurrence of local basement topography, which may act as a local buttress. Basement topography may, however, also favour incision and local preservation of detachment fault segments. Thus, the spatial organization of inherited structures (offsets of top basement, magmatic additions or extensional allochthons) and their relation to the imposed shortening direction can become key-factors in controlling local structures during reactivation.

\subsection{Control of inherited rift structures on the stacking of thrust sheets}

One of the major results based on the study of the Err and Platta nappes is that the apparent complexity observed on a map-scale (juxtaposition of lithologies of different origin) is due to the reactivation of a complex, non-layer cake rift architecture (Fig. 8). Indeed if Alpine D1 thrusts are analysed, they show a surprisingly simple thrust geometry made of major thrust contacts interleaved by duplex structures. More detailed studies of the Bardella-Fuorcla Cotschna area by Masini et al. (2012) showed that the sedimentary sequences observed in each of the subunits belong to one and the same supra-detachment basin and the composition of the breccias reflect the nature of the underlying basement. Thus, the apparent complexity is largely due to the complex inherited geology and less to the reactivation structures.

For the example of the Falotta-Tigias area, detailed mapping pointed out that the major serpentinised mantle forming subunit 1 (Figs. 6 and 7) forms the backbone of the lower Platta unit, while the other subunits are only local, and they disappear laterally over short distances. Thus, in contrast to previous interpretations (Ring et al. 1989; Dürr 1992; Hsü 1995) suggesting that the observed discontinuities may be the result of large offsets, the interpretation proposed here is that the subunits $2-7$ result from the sampling of the former hanging wall of the fault exhuming the mantle. This result is, however, at odds with the fact that the Err and Platta are part of a nappe stack that can be mapped through large parts of the Alps, being part of the suture zone. Thus, their continuity as paleogeographic domains assumes that important shortening had to be accommodated within the mountain belt during the emplacement of these units. This leads to the question about where and how strain has been accommodated during convergence. In classical fold and thrust belts major shortening preferentially occurs along some few master faults. In the example of the Err and Platta nappes, we suggest that the major structures that accommodated the offset are those that are in the footwall of the major basement units, which define second-order thrust faults 

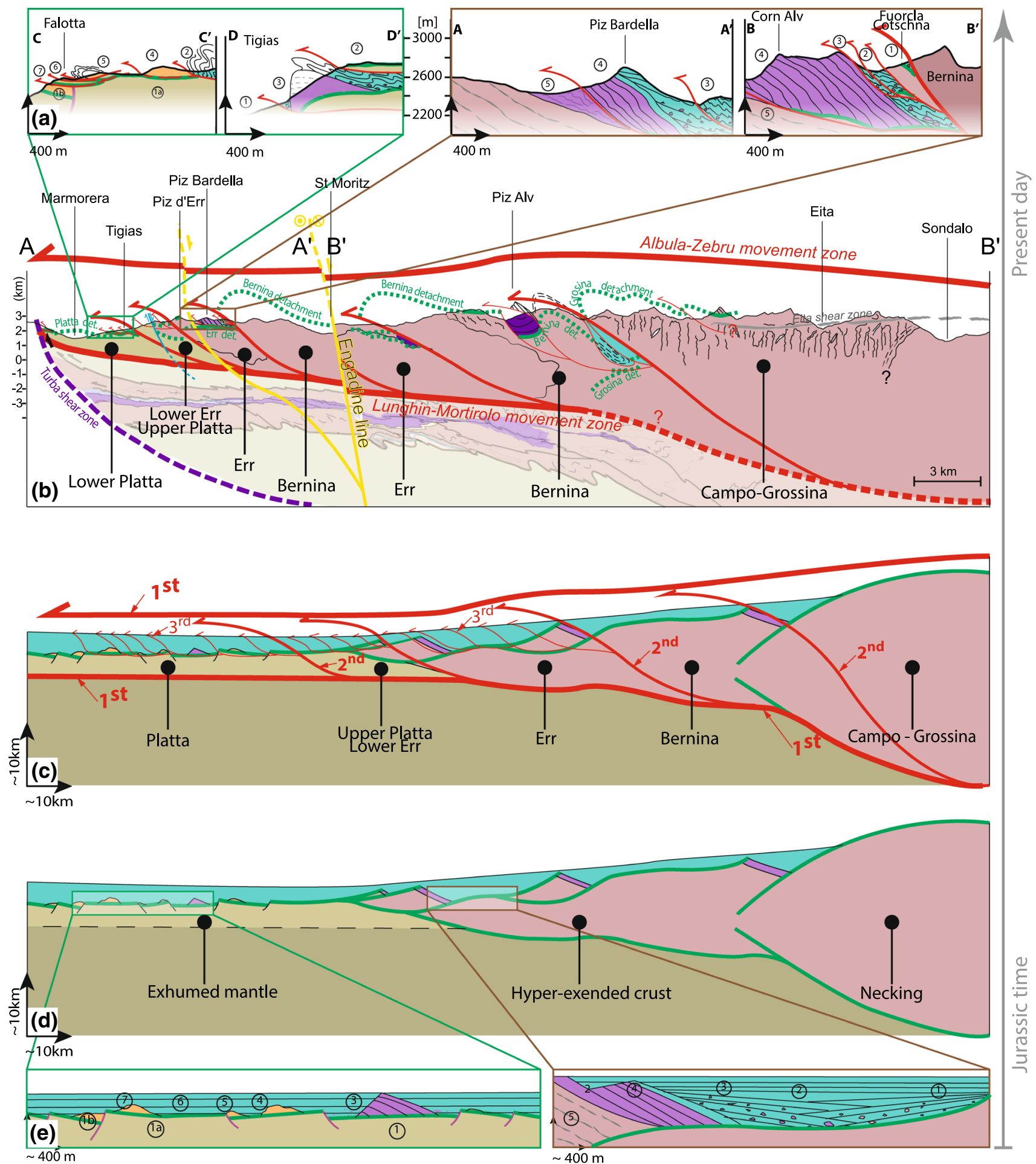

\begin{tabular}{|c|c|c|c|}
\hline Cover & Basement & Alpine structures & Jurassic rift structures \\
\hline $\begin{array}{l}\square \text { basalt } \\
\square \text { syn- and post-rift sediments } \\
\text { pre-rift sediments }\end{array}$ & $\begin{array}{l}\square \text { continental crust } \\
\square \text { serpentinised mantle } \\
\square \text { mantle }\end{array}$ & $\begin{array}{l}\angle \text { D1 first and second } \\
\text { order thrusts } \\
\longleftarrow \text { D1 third order thrust }\end{array}$ & $\begin{array}{l}\text { — Extensional fault } \\
\text { — Normal fault }\end{array}$ \\
\hline
\end{tabular}


4Fig. 8 Schematic sections across the present-day nappe stack and the former distal margin showing the main inherited structures and their role during reactivation (D1 stage). a Present-day constructed sections across the Bardella-Fuorcla Cotschna and Falotta-Tigias area (for more detail see Figs. 4 and 6). b Present-day Alpine section across the Upper Penninic and Austroalpine nappes, for loction see Fig. 3a.; modified after Mohn et al. 2011. c Architecture of the Adriatic margin based on the restoration of the Austroalpine nappe system, whith the location of futur D1 first, second and third order thrust. d Architecture of the Adriatic margin based on the restoration of the Austroalpine nappe system. e Restoration of the present-day geological sections discussed in this paper (for more detail see Figs. 5 and 7). Note the hierarchy of D1 thrust systems and the role of the inherited rift structures, in particular of the detachment systems during reactivation (for a more detailed discussion see text)

(Fig. 8). First order thrust faults (thick red line Fig. 8) are, as previously described by Mohn et al. (2012), the AlbulaZebru and Lunghin-Mortirolo fault systems that juxtapose different rift domains and accommodated most of the shortening in the nappe stack during Alpine convergence.

\subsection{Reactivation of inherited rift structures: from the local to the orogen scale}

Rift inheritance, in particular in former distal rifted margins, challenges the classical concept of nappe tectonics. While in classical interpretations most of the deformation found in the orogens is allocated to convergence, the question remains how important the inherited component may be and how far it may control the structure of the final orogen. Although the results of this study do not allow providing definitive answers to this question, the example of the Err and Platta nappes shows that it is fundamental to introduce rift inheritance in the study of collisional orogens. This is particularly true for examples that reactivate former distal margins. However, the scale of investigation and the hierarchy of fault systems may be important.

At a local scale "coherent thrust sheets", referred to as subunits, can be defined. These subunits are separated by thrusts (thin red line, Fig. 8) that decouple at very shallow levels, typically into ophicalcites or serpentinised top basement (e.g. Tigias-Falotta area, Figs. 7, 8). In this example the thrust sheets are locally derived, very thin and strongly controlled by the basement topography. While decoupling levels (e.g. former exhumed extensional detachment) can be continuous over several kilometres, the blocks and magmatic additions between the decoupling level and the post-rift sediments can disappear over short distances. This complex top basement architecture seems to strongly control the lateral variability found in subunits. In areas with more intense compressional overprint or in subduction related settings this variability can be erroneously interpreted as a tectonic mélange. In our study, we can show that these very thin slivers result from the accretion of hanging wall derived material without having accommodated minor amounts of shortening. We therefore classify these units as third order duplex-systems.

At a regional scale larger "coherent thrust sheets" can be mapped extending over wider areas [e.g. Upper and Lower Platta units; Desmurs et al. 2001). These units include a "basement" that forms the backbone of these units (in this case large slices of exhumed mantle, e.g. subunits 1 in the Tigias-Falotta example (Figs. 7, 8)]. These units form the backbone of the thrust sheets (e.g. Lower Platta unit and Upper Platta unit; e.g. Desmurs et al. 2001) that are interleaved by the third order duplex structures. These units are characterised by a continuous, massive "basement". The thrusts that bound these units can be mapped over tens of kilometres and have to be decoupled within the basement. We classify these structures as second order thrust systems.

At an orogenic scale first order nappe systems can be defined (e.g. Lower, Middle, Upper Austroalpine). Each of these systems originate from a different paleogeographic entity of the former margin (proximal, necking and distal margins) as indicated by the stratigraphic record (e.g. Mohn et al. 2011). The major thrusts systems corresponding to the Albula-Zebru and Lunghin-Mortirolo (thick red line, Fig. 8), and referred to as fist order structures, typically juxtapose nappe systems with different paleogeographic content.

\section{Conclusion}

This study shows that some of the complexity observed in orogens can be explained with the occurrence of inherited rift structures, independent of the scale of observation. The definition of nappe systems on an orogenic scale (1st order structures) is manly based on the stratigraphic and petrological content of the units. In contrast, defining and mapping 2nd and 3rd order regional and local scale structures in orogens is more difficult. In this study we focused on local scale 2nd and 3rd order structures and we show that, at this scale, geological "complexity" is strongly linked to the existence of inherited rift structures. In particular top basement topography (allochthonous blocks, magmatic additions, top basement offset by normal faults) and the existence or absence of efficient decoupling levels at the top basement appears to be controlling factors. Two major types of reactivations can be defined at a local scale: (1) classical thin-skin thrust systems associated with the formation of duplex along ramp flat systems; and (2) fold nucleation and amplification associated to local buttresses that may consist of either magmatic bodies, extensional allochthons or half graben type structures. While the 
first type depends mainly on the presence of potential decoupling horizons (detachment faults, hydration fronts, salt layers) the latter depends on the structure and orientation of the rift induced inheritance.

Although it may be too early to draw definitive conclusions, our study of the Bardella-Fuorcla Cotschna and Tigias-Falotta areas shows that the role of rift inheritance is a key to understand reactivation and final architecture of convergent systems on a local scale. Moreover, the role of inheritance may be scale dependent and obviously only applicable to domains that suffered rifting. Thus, detailed structural analysis of the post-rift sequence can be more meaningful to determine the more regional deformation history, if the occurrence of local buttresses can be excluded. In contrast, detailed structural studies of pre-, and syn-rift sequences need to include the potential existence of discontinuous, "nonlayer cake" units, i.e. pre-rift sediments can no more be restored back to continuous undeformed units prior to onset of shortening. Since orogens and in particular internal parts of Alpine type orogens are ideally sampling remnants of former distal margins, the detailed study of these units needs to verify if rift inheritance is present, and if yes, it needs to be included in the structural analysis. Therefore defining and using diagnostic criteria to describe and map the role of rift inheritance in collisional orogens is a prerequisite to describe reactivation in collisional orogens.

Acknowledgements The authors are grateful to the financial support of Total supporting the $\mathrm{PhD}$ of the fist author and to the very helpful and constructive remarks of the editor Stefan Schmid and critical reviews by Mark Handy and an anonymous reviewer. We would also like to thank the numerous colleagues from academia and industry that participated in field excursions through the study area and contributed in a constructive way to the work that we present in this paper.

\section{References}

Beaumont, C., Ellis, S., Hamilton, J., \& Fullsack, P. (1996). Mechanical model for subduction-collision tectonics of Alpinetype compressional orogens. Geology, 24(8), 675-678.

Beltrando, M., Manatschal, G., Mohn, G., Dal Piaz, G. V., Brovarone, A. V., \& Masini, E. (2014). Recognizing remnants of magmapoor rifted margins in high-pressure orogenic belts: the Alpine case study. Earth-Science Reviews, 131, 88-115.

Beltrando, M., Rubatto, D., \& Manatschal, G. (2010). From passive margins to orogens: The link between ocean-continent transition zones and (ultra) high-pressure metamorphism. Geology, 38(6), 559-562.

Bernoulli, D., \& Jenkyns, H. C. (1974). Alpine Mediterranean and central Atlantic Mesozoic facies in relation to the early evolution of the Tethys. In R. H. Dott \& R. H. Shaver (Eds.), Modern and ancient geosynlinal sedimentation (19th ed., pp. 129-160). Tulsa: Society of Economic Paleontologists and Mineralogists Special Publication.
Bernoulli, D., \& Weissert, H. (1985). Sedimentary fabrics in Alpine ophicalcites, south Pennine Arosa zone. Switzerland. Geology, 13(11), 755-758.

Boillot, G., Grimaud, S., Mauffret, A., Mougenot, D., Kornprobst, J., Mergoil-Daniel, J., et al. (1980). Ocean-continent boundary off the Iberian margin: a serpentinite diapir west of the Galicia Bank. Earth and Planetary Science Letters, 48(1), 23-34.

Bonatti, E., Emiliani, C., Ferrara, G., Honnorez, J., \& Rydell, H. (1974). Ultramafic-carbonate breccias from the equatorial Mid Atlantic Ridge. Marine Geology, 16(2), 83-102.

Boschi, C., Früh-Green, G. L., Delacour, A., Karson, J. A., \& Kelley, D. S. (2006). Mass transfer and fluid flow during detachment faulting and development of an oceanic core complex, Atlantis Massif (MAR $30^{\circ} \mathrm{N}$ ). Geochemistry, Geophysics, Geosystems, 7(1), Q01004, doi:10.1029/2005GC001074.

Butler, R. W. H., Tavarnelli, E., \& Grasso, M. (2006). Structural inheritance in mountain belts: An Alpine-Apennine perspective. Journal of structural geology, 28(11), 1893-1908.

Cornelius, H. P. (1932). Geologische Karte der Err-Julier-Gruppe 1: 25000. Schweizeriche Geologische Kommission Spezialkarte, $\mathrm{Nr}$ 115.

Cornelius, H. (1950). Geologie des Err-Julier-Gruppe: Der Gebirgsbau. Beträge zur Geologischen Karte Schweiz NF, 70(2), 1-264.

Cornelius, H. P., \& Clar, E. (1935). Erläuterungen zur geologischen Karte des Großglocknergebietes 1: 25.000. Geologische Bundesanstalt Wien.

Decandia, F. A. \& Elter, P. (1972). La "zona" ofiolitifera del Bracco nel settore compreso fra Levanto e la Val Graveglia (Appennino Ligure), Memorie della Società Geologica Italiana, 11(1), 503-530.

Desmurs, L., Manatschal, G., \& Bernoulli, D. (2001). The Steinmann Trinity revisited: mantle exhumation and magmatism along an ocean-continent transition: the Platta nappe, eastern Switzerland. Geological Society, London, Special Publications, 187, 235-266.

Desmurs, L., Müntener, O., \& Manatschal, G. (2002). Onset of magmatic accretion within a magma-poor rifted margin: a case study from the Platta ocean-continent transition, eastern Switzerland. Contributions to Mineralogy and Petrology, 144(3), 365-382.

Dietrich, V. (1970). Die Stratigraphie der Platta-Decke: Fazielle Zusammenhänge zwischen Oberpenninikum und Unterostalpin. Geologisches Institut der Eidg: Technischen Hochschule und der Universität Zürich.

Dunoyer de Segonzac, G., \& Bernoulli, D. (1976). Diagénèse et métamorphisme des argiles dans le Rhétien Sud-Alpin et Austroalpin (Lombardie et Grisons). Bulletin de la Société géologique de France, 18, 1283-1293.

Dürr, S. (1992). Structural history of the Arosa Zone between Platta and Err nappes east of Marmorera (Grisons): multi-phase deformation at the Penninic-Austroalpine plate boundary. Eclogae Geologicae Helvetiae, 85(2), 361-374.

Eberli, G. (1988). The evolution of the southern continental margin of the Jurassic Tethys Ocen as recorded in the Allgäu Formation of the Austroalpine Nappes of Graubünden (Switzerland). Eclogae Geologicae Helvetiae, 81(1), 175-214.

Escartín, J., Mével, C., MacLeod, C. J., \& McCaig, A. M. (2003). Constraints on deformation conditions and the origin of oceanic detachments: The Mid-Atlantic Ridge core complex at $15^{\circ}$ 45' N. Geochemistry, Geophysics, Geosystems, 4(8), doi:10. 1029/2002GC000472.

Ferreiro Mählmann, R. (1994). Zur Bestimmung von Diagenesehöhe und beginnender Metamorphose: Temperaturgeschichte und Tektogenese des Austroalpins und Südpenninikums in Vorarlberg und Mittelbünden. Institut für Geochemie: Petrologie und Lagerstättenkunde der Johann Wolfgang Goethe Universität. 
Ferreiro Mählmann, R. (1996). The pattern of diagenesis and metamorphism by vitrinite reflectance and illite-'crystallinity'in Mittelbünden and in the Oberhalbstein. Part 2: Correlation of coal petrographical and of mineralogical parameters. Schweizerische Mineralogische und Petrographische Mitteilungen, 76, 23-46.

Ferriere, J., Baumgartner, P. O., \& Chanier, F. (2016). The Maliac Ocean: the origin of the Tethyan Hellenic ophiolites. International Journal of Earth Sciences, 105, 1941-1963.

Finger, W. (1978). Die zone von Samaden (unterostalpine Decken, Graubünden) und ihre jurassischen Brekzien. Ph.D. dissertation, Diss. Naturwiss. ETH Zürich, Nr. 6145, 0000, NF 224:1-140.

Florineth, D., \& Froitzheim, N. (1994). Transition from continental to oceanic basement in the Tasna nappe (Engadine window, Graubunden, Switzerland)-Evidence for early cretaceous opening of the Valais Ocean. Schweizerische Mineralogische und Petrographische Mitteilungen, 74(3), 437-448.

Froitzheim, N., \& Eberli, G. P. (1990). Extensional detachment faulting in the evolution of a Tethys passive continental margin, Eastern Alps. Switzerland. Geological Society of America Bulletin, 102(9), 1297-1308.

Froitzheim, N., \& Manatschal, G. (1996). Kinematics of Jurassic rifting, mantle exhumation, and passive-margin formation in the Austroalpine and Penninic nappes (eastern Switzerland). Geological Society of America Bulletin, 108(9), 1120-1133.

Froitzheim, N., Pleuger, J., \& Nagel, T. J. (2006). Extraction faults. Journal of Structural Geology, 28(8), 1388-1395.

Froitzheim, N., Schmid, S. M., \& Conti, P. (1994). Repeated change from crustal shortening to orogen-parallel extension in the Austroalpine units of Graubünden. Eclogae Geologicae Helvetiae, 87(2), 559-612.

Furrer, H., Aemissegger, B., Eberli, G. P., Eichenberger, U., Frank, S., Naef, H., et al. (1985). Field workshop on Triassic and Jurassic sediments in the Eastern Alps of Switzerland, Mitteilungen aus dem Geologischen Institut der Eidgenoessischen Technischen Hochschule und der Universitaet Zuerich. Neue Folge, 248, 1-81.

Geiger, T. (1948). Manganerze in den Radiolariten Graubündens. Beiträge zur Geologischen Karte der Schweiz, N.F., 27, 89.

Gerya, T. V., Stöckhert, B., \& Perchuk, A. L. (2002). Exhumation of high-pressure metamorphic rocks in a subduction channel: A numerical simulation. Tectonics. doi:10.1029/2002TC001406.

Handy, M. (1996). The transition from passive to active margin tectonics: a case study from the Zone of Samedan (eastern Switzerland). Geologische Rundschau, 85(4), 832-851.

Handy, M. R., Herwegh, M., Kamber, B., Tietz, R., \& Villa, I. (1996). Geochronologic, petrologic and kinematic constraints on the evolution of the Err-Platta boundary, part of a fossil continent-ocean suture in the Alps (eastern Switzerland). Schweizerische Mineralogische und Petrographische Mitteilungen, 76(3), 453-474.

Handy, M., Herwegh, M., \& Regli, C. (1993). Tektomische Entwicklung der westlichen Zone von Samedan (Oberhalbstein, Graubuenden, Schweiz). Eclogae Geologicae Helvetiae, 86(3), 785-817.

Hsü, K. J. (1995). The geology of Switzerland: an introduction to tectonic facies. NJ: Princeton University Press Princeton.

Hsü, K. J., \& Briegel, U. (1991). Geologie der Schweiz. (p. 219). Switzerland: B. Birkäuser.

Incerpi, N., Marlire, L., Manatschal, G., \& Bernasconi, S. M. (2017). Evidence of hydrothermal fluid flow in a hyperextended rifted margin: the case study of the Err nappe (SE Switzerland). Swiss Journal of Geosciences, this volume, doi:10.1007/s00015-0160235-2.

Lagabrielle, Y., \& Bodinier, J. L. (2008). Submarine reworking of exhumed subcontinental mantle rocks: field evidence from the Lherz peridotites. French Pyrenees. Terra Nova, 20(1), 11-21.
Manatschal, G. (1995). Jurassic rifting and formation of a passive continental margin (Platta and Err nappes, Eastern Switzerland): geometry, kinematics and geochemistry of fault rocks and a comparison with the Galicia margin. Ph.D. dissertation, Eidgenossischen Technischen Hochschule Zürich, Nr. 11188.

Manatschal, G. (1999). Fluid-and reaction-assisted low-angle normal faulting: evidence from rift-related brittle fault rocks in the Alps (Err Nappe, eastern Switzerland). Journal of Structural Geology, 21(7), 777-793.

Manatschal, G. (2004). New models for evolution of magma-poor rifted margins based on a review of data and concepts from West Iberia and the Alps. International Journal of Earth Sciences, 93(3), 432-466.

Manatschal, G., \& Bernoulli, D. (1999). Architecture and tectonic evolution of nonvolcanic margins: Present-day Galicia and ancient Adria. Tectonics, 18(6), 1099-1119.

Manatschal, G., Engström, A., Desmurs, L., Schaltegger, U., Cosca, M., Müntener, O., et al. (2006). What is the tectono-metamorphic evolution of continental break-up: the example of the Tasna Ocean-Continent Transition. Journal of Structural Geology, 28(10), 1849-1869.

Manatschal, G., Froitzheim, N., Rubenach, M., \& Turrin, B. (2001). The role of detachment faulting in the formation of an oceancontinent transition: insights from the Iberia Abyssal Plain. Geological Society, London, Special Publications, 187(1), $405-428$.

Manatschal, G., Marquer, D., \& Früh-Green, G. L. (2000). Channelized fluid flow and mass transfer along a rift-related detachment fault (Eastern Alps, southeast Switzerland). Geological Society of America Bulletin, 112(1), 21-33.

Manatschal, G., \& Müntener, O. (2009). A type sequence across an ancient magma-poor ocean-continent transition: the example of the western Alpine Tethys ophiolites. Tectonophysics, 473(1), 4-19.

Manatschal, G., \& Nievergelt, P. (1997). A continent-ocean transition recorded in the Err and Platta nappes (Eastern Switzerland). Eclogae Geologicae Helvetiae, 90(1), 3-27.

Masini, E., Manatschal, G., \& Mohn, G. (2013). The Alpine Tethys rifted margins: Reconciling old and new ideas to understand the stratigraphic architecture of magma-poor rifted margins. Sedimentology, 60, 174-196.

Masini, E., Manatschal, G., Mohn, G., Ghienne, J. F., \& Lafont, F. (2011). The tectono-sedimentary evolution of a supra-detachment rift basin at a deep-water magma-poor rifted margin: the example of the Samedan Basin preserved in the Err nappe in SE Switzerland. Basin Research, 23, 652-677.

Masini, E., Manatschal, G., Mohn, G., \& Unternehr, P. (2012). Anatomy and tectono-sedimentary evolution of a rift-related detachment system: The example of the Err detachment (central Alps, SE Switzerland). Geological Society of America Bulletin, 124(9-10), 1535-1551.

Mohn, G., Manatschal, G., Beltrando, M., \& Haupert, I. (2014). The role of rift-inherited hyper-extension in Alpine-type orogens. Terra Nova, 26, 347-353.

Mohn, G., Manatschal, G., Beltrando, M., Masini, E., \& Kusznir, N. (2012). Necking of continental crust in magma-poor rifted margins: Evidence from the fossil Alpine Tethys margins. Tectonics, 31(1), TC1012. doi:10.1029/2011TC002961.

Mohn, G., Manatschal, G., Masini, E., \& Müntener, O. (2011). Riftrelated inheritance in orogens: a case study from the Austroalpine nappes in Central Alps (SE-Switzerland and N-Italy). International Journal of Earth Sciences, 100(5), 937-961.

Mohn, G., Manatschal, G., Müntener, O., Beltrando, M., \& Masini, E. (2010). Unravelling the interaction between tectonic and sedimentary processes during lithospheric thinning in the Alpine Tethys margins. International Journal of Earth Sciences, 99(1), 75-101. 
Montadert, L., et al. (1979). Initial Reports of the Deep Sea Drilling Project (Vol. 48). Brest: US Government Printing Office.

Müntener, O., Pettke, T., Desmurs, L., Meier, M., \& Schaltegger, U. (2004). Refertilization of mantle peridotite in embryonic ocean basins: trace element and $\mathrm{Nd}$ isotopic evidence and implications for crust-mantle relationships. Earth and Planetary Science Letters, 221, 293-308.

Naef, M. H. (1987). Ein Beitrag zur Stratigraphie der Trias-Serien im Unterostalpin Graubündens. Ph.D. dissertation, Diss. Naturwiss. ETH Zürich, Nr. 8236, 1987.

Nievergelt, P., Liniger, M., Froitzheim, N., \& Mählmann, R. F. (1996). Early to mid Tertiary crustal extension in the Central Alps: The Turba mylonite zone (eastern Switzerland). Tectonics, 15, 329-340.

Osmundsen, P., \& Ebbing, J. (2008). Styles of extension offshore mid-Norway and implications for mechanisms of crustal thinning at passive margins. Tectonics, 27(6), TC6016. doi:10.1029/ 2007 TC002242.

Péron-Pinvidic, G., Manatschal, G., Minchull, T. A., \& Sawyer, D. S. (2007). Tectonosedimentary evolution of the deep Iberia-Newfoundland margins: Evidence for a complex breakup history. Tectonics, 26(2), TC2011. doi:10.1029/2006TC001970.

Peron-Pinvidic, G., Manatschal, G., \& Osmundsen, P. T. (2013). Structural comparison of archetypal Atlantic rifted margins: a review of observations and concepts. Marine and Petroleum Geology, 43, 21-47.

Peters, T. (2005). Blatt Nr. 1257 St.Moritz - Geol. Atlas der Schweiz 1:25'000, Karte 118, mit Erläuterungen. Bundesamt für Wasser und Geologie, Bern.

Peters, T. (2007). Blatt Nr. 1256 Bivio. Geol. Atlas der Schweiz 1:25’000, Karte 124, mit Erläuterungen. Bundesamt für Wasser und Geologie.

Picazo, S., Manatschal, G., Cannat, M., \& Andréani, M. (2013). Deformation associated to exhumation of serpentinized mantle rocks in a fossil Ocean Continent Transition: The Totalp unit in SE Switzerland. Lithos, 175, 255-271.

Pinto, V. H. G., Manatschal, G., Karpoff, A. M., \& Viana, A. (2015). Tracing mantle-reacted fluids in magma-poor rifted margins: The example of Alpine Tethyan rifted margins. Geochemistry, Geophysics, Geosystems, 16(9), 3271-3308.

Reston, T. (2009). The structure, evolution and symmetry of the magma-poor rifted margins of the North and Central Atlantic: a synthesis. Tectonophysics, 468(1), 6-27.

Ring, U., Ratschbacher, L., Frisch, W., Biehler, D., \& Kralik, M. (1989). Kinematics of the Alpine plate-margin: structural styles, strain and motion along the Penninic-Austroalpine boundary in the SwissAustrian Alps. Journal of the Geological Society, 146(5), 835-849.

Ring, U., Ratschbacher, L., Frisch, W., DÜrr, S., \& Borchert, S. (1990). The internal structure of the Arosa zone (Swiss-Austrian Alps). Geologische Rundschau, 79(3), 725-739.

Robertson, A. H. (2007). Geochemical evidence for the sedimentary and diagenetic development of the Mesozoic-Early Cenozoic Newfoundland rifted margin, Northwest Atlantic (Ocean Drilling program leg 210, site 1276) (pp. 1-63). Texas, US: Government Printing office College Station.

Schaltegger, U., Desmurs, L., Manatschal, G., Müntener, O., Meier, M., Frank, M., et al. (2002). The transition from rifting to seafloor spreading within a magma-poor rifted margin: field and isotopic constraints. Terra Nova, 14(3), 156-162.

Schmid, S., \& Froitzheim, N. (1993). Oblique slip and block rotation along the Engadine line. Eclogae Geologicae Helvetiae, 86(2), $569-593$.
Spillmann, P., \& Büchi, H. I. (1993). The Pre-Alpine Basement of the Lower Austro-Alpine Nappes in the Bernina Massif (Grisons, Switzerland. Valtellina: The Pre-Mesozoic Geology of Alps.

Staub, R. (1946). Geologische Karte der Berninagruppe und ihrer Umgebung im Oberengadin, Bergell, Val Malenco, Puschlav und Livigno, 1:50,000, Nr. 118. Zürich: herausgegeben von der Geologischen Kommission der Schweizerischen Naturforschenden Gesellschaft.

Steinmann, G. (1925). Gibt es fossile Tiefseeablagerungen von erdgeschichtlicher Bedeutung? Geologische Rundschau, 16(6), $435-468$.

Steinmann, G. (1927). Die ophiolitschen Zonen in den mediterranen Kettengebirgen. Translanted and reprinted by Bernoulli and Friedman. In Dilek \& Newcomb (Eds.), Ophiolite Concept and the Evolution of Geologic Thought. Geological Society America Special Publlications, 373, 77-91.

Stöcklin, J. (1974). Possible ancient continental margins in Iran. Berlin Heidelberg: Springer.

Treves, B. E., \& Harper, G. D. (1994). Exposure of serpentinites on the ocean floor: sequence of faulting and hydrofracturing in the Northern Apennine ophicalcites. Ofioliti, 19(4), 435-466.

Treves, B., Hickmott, D., \& Vaggelli, G. (1995). Texture and microchemical data of oceanic hydrothermal calcite veins. Northern Apennine ophicalcites. Ofioliti, 20(2), 111-122.

Trommsdorff, V., Montrasio, A., Hermann, J., Muntener, O., Spillmann, P., \& Giere, R. (2005). The geological map of Valmalenco. Schweizerische Mineralogische und Petrographische Mitteilungen, 85(1), 1-13.

Trommsdorff, V., Piccardo, G., \& Montrasio, A. (1993). From magmatism through metamorphism to sea floor emplacement of subcontinental Adria lithosphere during pre-Alpine rifting (Malenco, Italy). Schweizerische Mineralogische und Petrographische Mitteilungen, 73(2), 191-203.

Trümpy, R. (1975). Penninic-Austroalpine boundary in the Swiss Alps: a presumed former continental margin and its problems. American Journal of Science, 275, 209-238.

Trümpy, R. (1977). The Engadine Line: a sinistral wrench fault in the Central Alps. Geological Society of China.

Tugend, J., Manatschal, G., Kusznir, N., Masini, E., Mohn, G., \& Thinon, I. (2014). Formation and deformation of hyperextended rift systems: Insights from rift domain mapping in the Bay of Biscay-Pyrenees. Tectonics, 33(7), 1239-1276.

Unternehr, P., Péron-Pinvidic, G., Manatschal, G., \& Sutra, E. (2010). Hyper-extended crust in the South Atlantic: in search of a model. Petroleum Geoscience, 16(3), 207-215.

von Rath, G. (1857). Geognostische Bemerkungen über das Berninagebirge in Graubünden. Berlin: Z Deutsche Geolologische Gesellschaft.

Weissert, H. J., \& Bernoulli, D. (1985). A transform margin in the Mesozoic Tethys: evidence from the Swiss Alps. Geologische Rundschau, 74(3), 665-679.

Whitmarsh, R., \& Wallace, P. (2001). The rift-to-drift development of the West Iberia non-volcanic continental margin; a review of the contribution of Ocean Drilling Program Leg 173. Proceedings of the Ocean Drilling Project Scientific Results, 173, 1-36.

Wilson, R., Manatschal, G., \& Wise, S. (2001). Rifting along nonvolcanic passive margins: stratigraphic and seismic evidence from the Mesozoic successions of the Alps and western Iberia. Geological Society, London, Special Publications, 187, 429-452. 